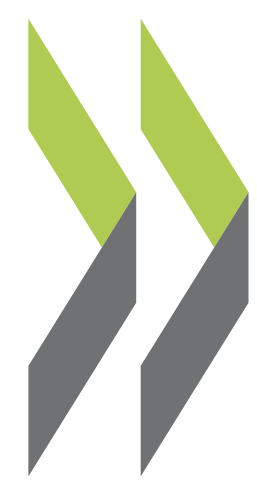

OECD Economics Department Working Papers No. 276

Making Growth More Environmentally Sustainable in Germany

\section{Grant Kirkpatrick,}

Gernot Klepper,

Robert Price 


\section{MAKING GROWTH MORE ENVIRONMENTALLY SUSTAINABLE IN GERMANY}

ECONOMICS DEPARTMENT WORKING PAPERS No. 276

by

Grant Kirkpatrick, Gernot Klepper and Robert Price

Most Economics Department Working Papers beginning with No. 144 are now available through OECD's Internet Web site at http://www/oecd.org/eco/eco/ 


\begin{abstract}
RÉSUMÉ
This document analyses German environmental policies, including, among others, discussion of air and water quality policy, use of the waste management hierarchy approach and of voluntary agreements. The German public has been highly sensitive to environmental concerns, leading to many policy initiatives in this area since the early 1980s. Significant environmental improvements have been achieved, using an approach frequently based on detailed regulations, often developed with the close involvement of industry and even individual polluters. There has developed a tendency to relieve some of the heaviest polluters from the most stringent regulation, on the grounds of competitiveness concerns, and some polluting activities receive considerable direct or indirect subsidies; these policies will increasingly make it unnecessarily expensive to meet environmental targets. Objectives need to be defined more clearly and consistently and a less discriminatory approach to taxation and regulation needs to be applied. Increasing the use of economic incentives, using taxation or tradable permits systems, applied with the maximum degree of uniformity, can help to reduce the costs of environmental policy in the future.
\end{abstract}

JEL Classification: H23, Q00, Q20, Q28, Q40, Q48.

Keywords: Germany, sustainable development, environmental policy.

$* * * *$

Ce document analyse les politiques environnementales de l'Allemagne, en particulier les politiques pour l'air et l'eau, l'utilisation de l'approche de la hiérarchie de traitement des déchets et des approches volontaires. L'opinion allemande est très sensibilisée aux problèmes d'environnement, ce qui a mené depuis le début des années 80 à de nombreuses initiatives de politique dans ce domaine. Des progrès significatifs ont été accomplis, en utilisant le plus souvent une approche fondée sur des réglementations détaillées, développées en étroite coopération avec l'industrie et même les pollueurs individuels. En général, les pollueurs les plus importants ont eu tendance à être exemptés des réglementations les plus strictes, du fait de préoccupations de compétitivité, et certaines activités polluantes reçoivent des subventions directes ou indirectes considérables; ces politiques rendront de plus en plus inutilement coûteuse la réalisation des objectifs environnementaux. Les objectifs devraient aussi être définis plus clairement et de façon plus cohérente, et la taxation et les réglementations devraient être appliquées de manière moins discriminatoire. Utiliser plus d'instruments économiques tels que la taxation et les marchés de permis d'émission, avec un degré maximum d'uniformité, aiderait à réduire les coûts de politique de l'environnement dans le futur.

Classification JEL: H23, Q00, Q20, Q28, Q40, Q48.

Mots clés: Allemagne, développement durable, politique environnementale.

Copyright: OECD, 2001. All rights reserved.

Applications for permission to reproduce or translate all, or part of, this material should be made to: Head of Publications Service, OECD, 2 rue André-Pascal, 75775 PARIS CEDEX 16, France 


\section{TABLE OF CONTENTS}

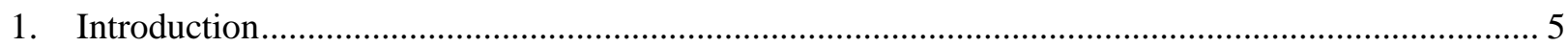

2. Environmental issues: concerns, objectives and performance ................................................... 6

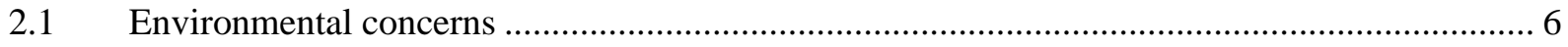

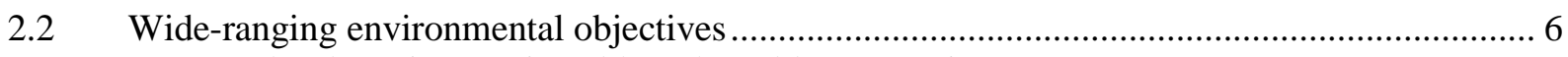

2.3 Progress has been impressive although problems remain...................................................... 9

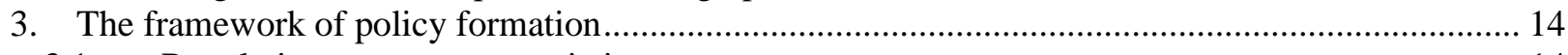

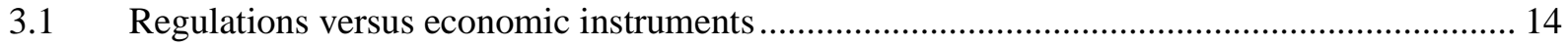

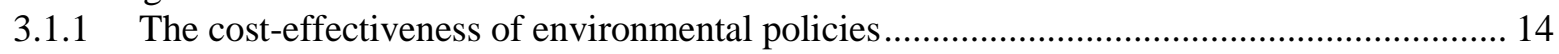

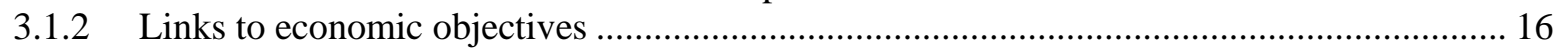

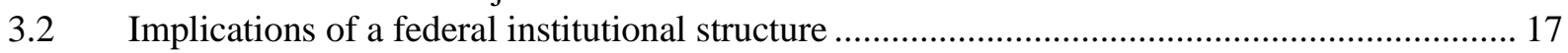

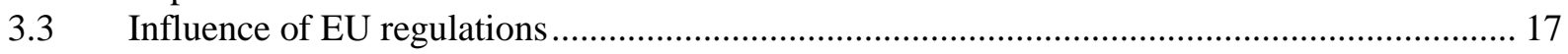

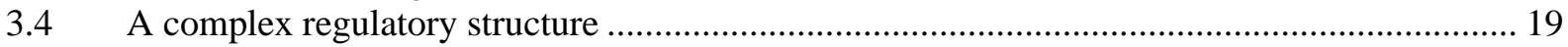

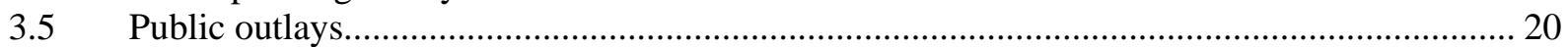

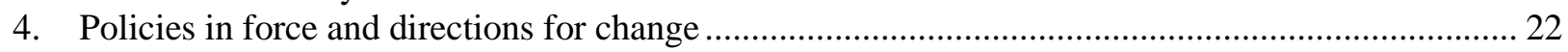

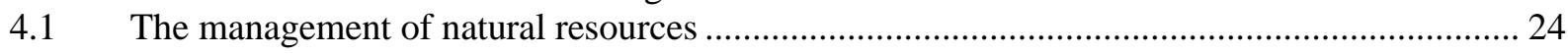

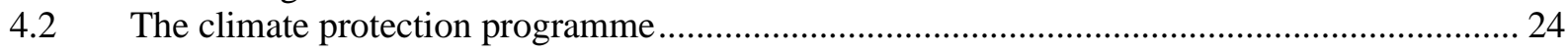

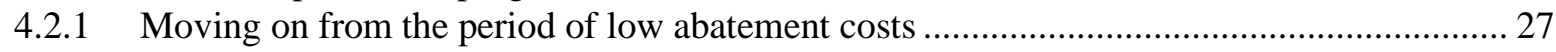

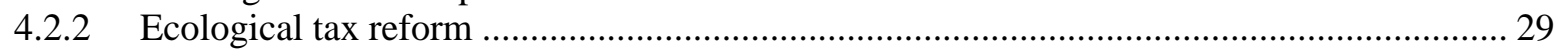

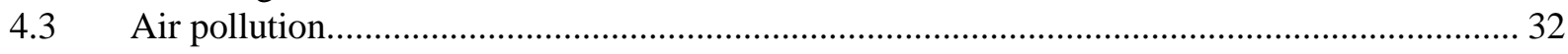

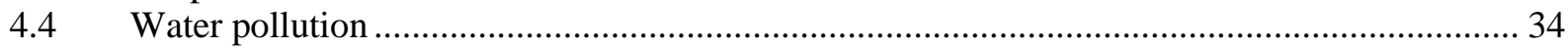

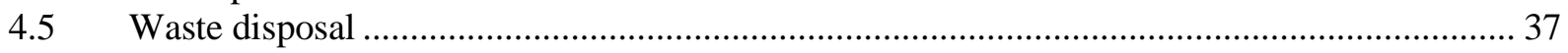

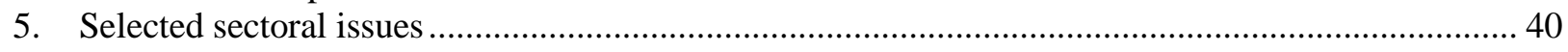

5.1 Electricity: reconciling efficient supply with environmental objectives ................................. 41

5.1.1 Liberalisation and the promotion of alternative sources of energy .................................... 41

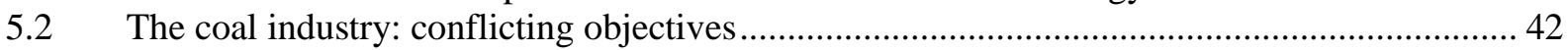

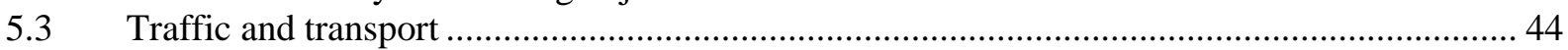

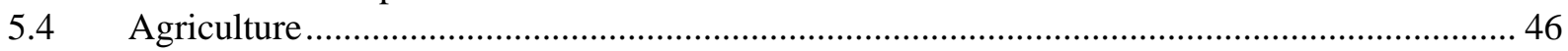

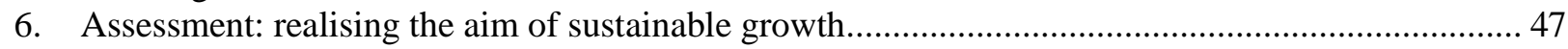

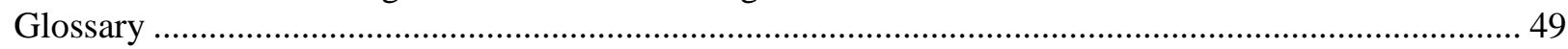

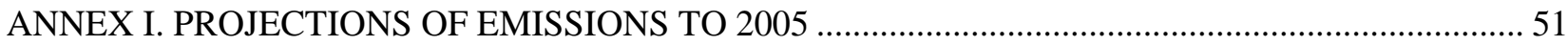

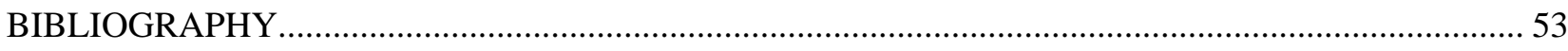




\section{Boxes}

1. Despite lower levels of pollution, damage to forests has not been reduced significantly.......... 13

2. The role of the EU in environmental policy............................................. 18

3. Voluntary agreements/arrangements in environmental policy ............................ 20

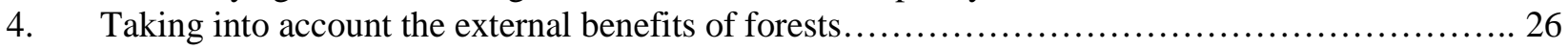

5. Competitiveness considerations in the environmental tax debate............................... 31

6. $\mathrm{NO}_{\mathrm{x}}$ emissions charge in Sweden: positive experience.................................... 33

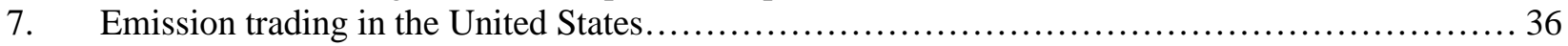

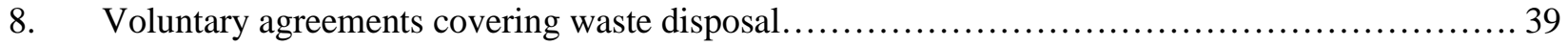

\section{Tables}

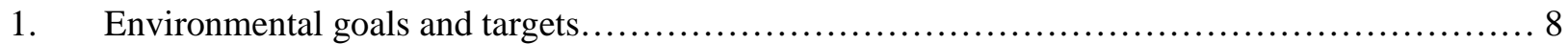

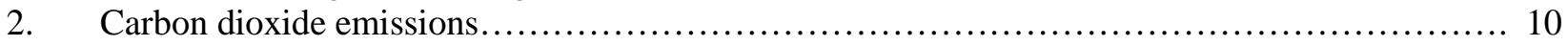

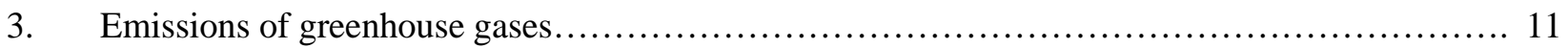

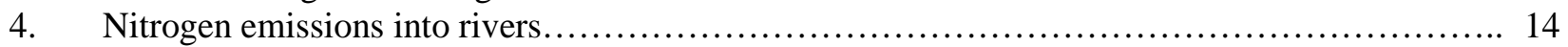

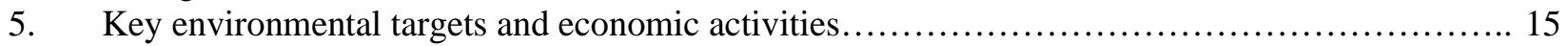

6. Environmental expenditure on pollution abatement and control............................. 21

7. Expenditure on environmental protection in the old Länder.............................. 22

8. Carbon dioxide reduction achieved by industries signing the voluntary agreement...............28

9. Optimal composition of carbon dioxide emissions from energy use, old Länder................. 29

10. Effective taxation of energy sources......................................................... 32

\section{Figures}

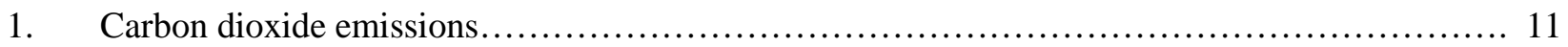

2. Heavy metal concentrations in the Rhine at the Dutch border................................. 12

3. National indicators of progress toward sustainable development............................ 23

4. Marginal abatement of $\mathrm{CO}_{2}$ reduction in the old Länder...................................... 27

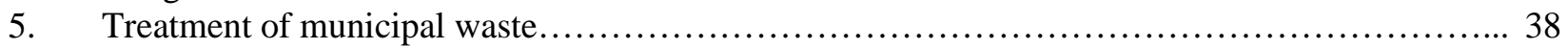

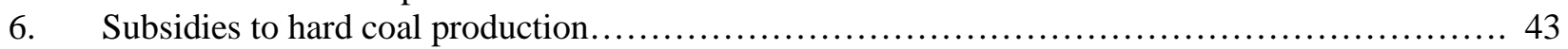

7. The financial aid programme to the coal industry............................................ 44

Annex tables

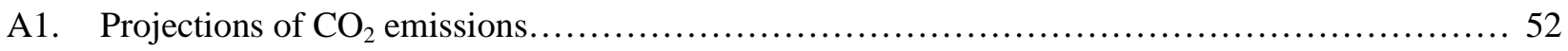

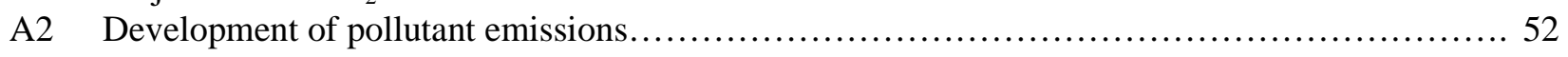


ECO/WKP(2001)2

\title{
MAKING GROWTH MORE ENVIRONMENTALLY SUSTAINABLE IN GERMANY ${ }^{1}$
}

\author{
Grant Kirkpatrick, Gernot Klepper and Robert Price ${ }^{2}$
}

\section{Introduction}

1. Sustainable development issues have increasingly started to influence policy making in the OECD area, especially since the Rio Conference in 1992, and they have been made a top priority for the work of the OECD. Germany has also been strongly influenced by this trend and indeed since 1994 the concept of sustainable development has been incorporated into the federal German constitution, which recognises the preservation of "the means of life for future generations" as a fundamental aim of the state. The country's future environmental goals are ambitious and far-reaching, based on an impressive performance over the past fifteen years, which have seen marked improvements in air and water quality and a proven degree of flexibility in achieving this. Environmental objectives include reducing carbon dioxide emissions by a quarter by the middle of the coming decade, gradually phasing out nuclear power and further improving environmental conditions in both cities and the countryside. However, the easiest and least costly improvements have probably already been exploited, and herein lies the key economic issue; how to achieve environmental targets at the least cost to existing generations in terms of employment and growth. Care will be needed to ensure that the tradeoffs -- or indeed complementarities -between environmental and economic objectives are properly evaluated. This involves a complex set of issues, and especially so since policy choices with respect to climate policy will also depend crucially on the ability to persuade other countries to co-operate and this will influence the type of instruments to be considered.

2. The paper examines the economic issues which are emerging as environmental policy shifts from dealing with the effects of local environmental excesses to defining and achieving an environmental strategy for achieving sustainable growth. In the first section it describes Germany's environmental objectives and provides a short review of past and likely future environmental performance. It then describes the political and institutional background, which has resulted de facto in a complex regulatory structure in which the links between environmental and economic efficiency objectives are not only unclear but have often not been fully assessed; particular controversy exists as to the employment effects of environmental policies. Against this background, the third section outlines the economic policy issues and choices that arise in attempting to meet current and future environmental objectives, given that the evidence suggests that some targets might not be reached unless further policy measures are taken and that the associated costs are likely to be greater than in the past. In the same vein, the fourth section analyses important selected sectoral issues in more detail, including policy in the electricity, coal, transport and agriculture sectors. A final section draws together the broader issues and presents conclusions.

1. This paper was originally produced for the OECD Economic Survey of Germany, which was published in November 1999 under the authority of the Economic Development Review Committee. Working papers on the same subject have been published for Norway, Finland, the US and Denmark, and are forthcoming for other countries.

2. Gernot Klapper is a consultant from the Institute of World Economics, Kiel, Germany; Grant Kirkpatrick and Robert Price are both members of the Economics Department of the OECD. The authors would like to thank Eckhard Wurzel for his contribution, and Sylvie Toly, Janice Gabela and Veronica Humi for their technical support. 


\section{Environmental issues: concerns, objectives and performance}

\subsection{Environmental concerns}

3. Germany is characterised by a high level of political and societal sensitivity to environmental issues and there are a number of reasons for this concern. Population density and industrialisation are high and agriculture is intensive. The transport network is dense with high rates of traffic growth. Germany has become a major transit route for traffic in all directions as European integration has strengthened. There is also a long history of having to cope with trans-boundary problems: the coastline is long; there are borders with nine other countries, and most of the rivers have their sources in other states. Imported air pollution from the planned economies of eastern Europe was a major concern in the past and Germany is presently both an "importer" and "exporter" of pollutants.

4. Economic growth was exceptionally rapid following the war but by the 1960s, such development was seen as being accompanied, in the popular view, by deteriorating water quality and increasing air pollution, which were considered as a potential threat to human health. Pollution of both the air and the aquatic environment by household and industrial effluents became more evident to the public through dying and damaged forests and by major outbreaks of algae in both the North Sea and the Baltic. At the same time, several accidents in the chemicals industry heightened public awareness -- as did Chernobyl. Sensitivity to environmental matters continued to increase through the 1980s and 1990s -- reinforced by the environmental situation in the new Länder -- with the focus broadening from local environmental problems toward global issues -- and global commitments -- related not only to greenhouse gases but also to natural resource use more generally. By the mid-1990s fully half the population perceived the environment to be bad or very bad (Umweltbundesamt 1997b).

\subsection{Wide-ranging environmental objectives}

5. In response to rising public sensitivity environmental policy has been both broadened and deepened in the 1990s, leading to the adoption of a broadly based notion of "sustainable growth" as an overall policy aim, ${ }^{3}$ and it is in this context that the current debate about natural resource use is taking place. German environmental strategy is based on the attainment of six goals which are considered as underpinning "sustainable development". They are:"

- Protection of the climate and the ozone layer;

- Preserving an ecological balance;

- Reducing the use of natural resources;

- Safeguarding human health;

- Developing environmentally compatible forms of mobility;

- Propagating environmental ethics.

These goals have been widely discussed with a view to setting more specific environmental objectives and targets for achieving sustainable development. The Environmental Action Programme of the EU also lays down specific objectives. ${ }^{5}$ A non-exhaustive list of goals and proposed targets is presented in Table 1. So

3. See BMU (1998a).

4. $\quad$ BMU (1997).

5. The process of making the concept of sustainability operational has proceeded along several complementary paths and is not yet complete. At the political and consensus building level, talks were started in June 1996 with 130 representatives of industry, environmental and consumer organisations, trade 
far, the specific commitments of the German government are relatively few, key exceptions being international commitments to the reduction of greenhouse gas emissions, the elimination of ozone depleting substances and the phasing out of nuclear power. ${ }^{6}$

6. Central to achieving environment goals are both natural resource management, such as the preservation of biodiversity by better land use management and the preservation of forests, and environmental management. Three longer-term rules have been adopted which should form the basis for the complex task of resource and environmental management: ${ }^{7}$

- Regeneration: the extraction rate of renewable resources should not exceed the regeneration rate.

- Substitution: the extraction rate of non-renewable resources should not exceed the rate of substitution with other resources or capital.

- Adaptability: emission levels should not exceed the rate of assimilation of the environment.

Environmental management covers urban pollution problems such as smog and acidification, which has been responsible for reducing water quality (which in turn threatens biodiversity) and the destruction of forests, avoiding algae plagues in coastal and inland waters (eutrophication) and the avoidance of global warming. To achieve these goals involves both the reduction of greenhouse gas emissions, the most important of which is carbon dioxide, and reductions in the emissions of sulphur and nitrogen oxides into the air and nitrates into the water. For the other greenhouse gases (methane $\left(\mathrm{CH}_{4}\right)$; nitrous oxide $\left(\mathrm{N}_{2} \mathrm{O}\right)$; fluoro carbons (PFCs, HFCs); sulphur hexafluoride $\left(\mathrm{SF}_{6}\right)$; carbon monoxide $(\mathrm{CO})$ and nitrogen oxides $\left(\mathrm{NO}_{\mathrm{x}}\right)$ ), no comprehensive reduction policy with specific targets has been formulated so far, although the "Carbon Dioxide Reduction Inter-ministerial Working Group" ${ }^{8}$ has elaborated targets, as has the Enquete Kommission of the German parliament (1995). Nevertheless, despite the lack of clear quantitative targets, a number of measures have been introduced by the government. Great emphasis has also been placed on reducing refuse not only to avoid local environmental problems such as the destruction of the soil and pollution of water supplies, but also to preserve world natural resources more generally.

7. While the reduction of specific emissions might impact on several environmental objectives, there are also in some instances policy conflicts. For example, reducing $\mathrm{NO}_{\mathrm{x}}$ emissions from cars through the use of catalytic converters so as to reduce acidification and improve the urban environment involves greater emissions of carbon dioxide for any given level of traffic; diesel cars may reduce green house gas emissions but can raise the emission of carcinogenic substances.

unions, scientists and all levels of government with a view to forming a national environmental policy plan for sustainable development. Although no consensus about the role and contents of such a plan was reached, a programme of measures was drawn up in April 1998. A number of local governments have also established their own plans (the Agenda 21 process). The present government wants to continue this debate with a view to setting concrete policy targets.

6. According to the Report to the Special Session of the United Nations General Assembly on Environment and Development in 1997 in New York this process of discussion about specific objectives has not been completed yet. BMU (1997).

7. These management rules were proposed in the 1996 Report of the German Council of Environmental Advisors (SRU, 1996) and by the Enquete Kommission of the German Parliament on the Protection of Humanity and the Environment (Deutscher Bundestag, 1998b).

8. $\quad$ Bundesregierung, IWG (1998). 
ECO/WKP(2001)2

Table 1. Environmental goals and targets

\begin{tabular}{|c|c|c|c|}
\hline \multirow{2}{*}{ Goals } & \multicolumn{2}{|c|}{ Environmental targets } & \multirow{2}{*}{$\begin{array}{l}\text { Targets proposed by other } \\
\text { institutions }\end{array}$} \\
\hline & German Government & EU & \\
\hline \multirow[t]{2}{*}{ Preserve the climate } & $\begin{array}{l}\mathrm{CO}_{2} \text { reduction of } 25 \text { per cent by } \\
2005 \text { (basis 1990) }\end{array}$ & $\begin{array}{l}\text { Kyoto-Protocol: reduction } \\
\text { of } 21 \text { per cent by } 2008 / 12 \\
\text { within the EU envelope of } \\
\text { an } 8 \text { per cent reduction. }\end{array}$ & $\begin{array}{l}\text { Diverse proposals, far beyond the } \\
\text { political targets. }\end{array}$ \\
\hline & $\begin{array}{l}\text { UNFCCC: stabilisation of } \\
\text { greenhouse gas } \\
\text { concentrations. }\end{array}$ & $\begin{array}{l}\text { EAP: stabilisation of } \\
\text { greenhouse gas } \\
\text { concentration. }\end{array}$ & \\
\hline \multirow[t]{2}{*}{$\begin{array}{l}\text { Stop depletion of the ozone } \\
\text { layer }\end{array}$} & Montreal Protocol & $\begin{array}{l}\text { Elimination of ozone } \\
\text { depleting substances. } \\
\text { Exceptions only up to } \\
5 \text { per cent of } 1990 \\
\text { consumption. }\end{array}$ & $\begin{array}{l}\text { Reduction of concentration in } \\
\text { stratosphere to } 1,3 \mathrm{ppb} \text { chloride } \\
\text { (UBA, 1995). }\end{array}$ \\
\hline & & & $\begin{array}{l}\text { Prohibition of HCFCs (SRU, } \\
\text { 1996). }\end{array}$ \\
\hline $\begin{array}{l}\text { Reduce eutrophication } \\
\text { in rivers and lakes }\end{array}$ & $\begin{array}{l}\text { Third North Sea Conference } \\
\text { Agreement to cut nitrates by } \\
50 \text { per cent }\end{array}$ & $\begin{array}{l}\text { EAP (1992): } \\
\text { Significant reduction of } \\
\text { nitrates in rivers and lakes } \\
\text { with more than } 50 \mathrm{mg} / \mathrm{l} . \\
\text { Stabilisation and reduction } \\
\text { of } \mathrm{N} \text {-concentration in } \\
\text { groundwater by } 2000 .\end{array}$ & $\begin{array}{l}\text { Wuppertal Institute (1995): } \\
\text { Elimination of chemical fertiliser by } \\
2010 ; \text { N-emission reduction by } \\
60 \text { per cent for } 2010 \text { and by } 80 \text { to } \\
90 \text { per cent by } 2020 \text {. }\end{array}$ \\
\hline Lower acidification of rain & $\begin{array}{l}\mathrm{SO}_{\mathrm{x}}-- \text { lower the } 1990 \text { emission } \\
\text { levels by } 80 \text { per cent by } 2005 \\
\mathrm{NO}_{x}-- \text { expect decline by } 19 \text { per } \\
\text { cent but no further } \\
\text { Target }\end{array}$ & $\begin{array}{l}\text { EAP (1992): } \\
\mathrm{SO}_{x} \text { reduction } 35 \text { per cent } \\
\text { in } 2000 \text { (basis 1985). } \\
\mathrm{NO}_{x} \text { stabilisation on } 1990 \\
\text { levels }\end{array}$ & $\begin{array}{l}\text { Wuppertal Institute ( } 1995) \text { : } \\
\mathrm{SO}_{2} \text { reduction } 80-90 \text { per cent by } \\
2010 \text {. } \\
\mathrm{NO}_{x} \text { reduction } 80 \text { per cent by } \\
2005 \text {. } \\
\mathrm{NH}_{3} \text { reduction } 80 \text { to } 90 \text { per cent by } \\
2010 \text {. } \\
\mathrm{NH}_{3} \text { reduction } 80 \text { to } 90 \text { per cent by } \\
2010 \text {. } \\
\mathrm{SRU} \text { (1994): } \\
\mathrm{NO}_{x} \text { reduction by } 80 \text { per cent in } \\
2010 \text {. }\end{array}$ \\
\hline $\begin{array}{l}\text { Improve the urban } \\
\text { Environment }\end{array}$ & & $\begin{array}{l}\text { EAP (1992): } \\
\mathrm{SO}_{x} \text { and } \mathrm{NO}_{x} \text { as above. } \\
\text { Noise levels below } \\
65 \mathrm{~dB}(\mathrm{~A}) \text { in nightly } \\
\text { equivalent levels. }\end{array}$ & $\begin{array}{l}\text { VOC reduction } 80 \text { per cent by } \\
2005 \text { (basis } 1987) \text {. } \\
\text { Noise: } 55 \mathrm{~dB}(\mathrm{~A}) \text { daytime, } 35- \\
45 \mathrm{~dB}(\mathrm{~A}) \text { night. } \\
\text { UBA (1995): } \\
\text { Noise: below } 65 \mathrm{~dB}(\mathrm{~A}) \text { daytime, } \\
\text { later below } 50 \mathrm{~dB}(\mathrm{~A}) \text {. }\end{array}$ \\
\hline Preserve biodiversity & $\begin{array}{l}10 \text { per cent of area of } \\
\text { Germany as an interconnected } \\
\text { net of protected areas. }\end{array}$ & $\begin{array}{l}\text { EAP (1992): } \\
\text { Interconnected net of } \\
\text { protected natural areas. }\end{array}$ & $\begin{array}{l}\text { SRU (1994): } \\
10 \text { per cent of the area of } \\
\text { Germany should be protected; } \\
5 \text { per cent without any human } \\
\text { interference. } \\
\text { Wuppertal Institute (1995): } \\
\text { Stabilisation of urban land use. }\end{array}$ \\
\hline
\end{tabular}


Table 1. Environmental goals and targets (continued)

\begin{tabular}{|c|c|c|c|}
\hline \multirow{2}{*}{ Goals } & \multicolumn{2}{|c|}{ Environmental targets } & \multirow{2}{*}{$\begin{array}{l}\text { Objectives proposed by other } \\
\text { institutions }\end{array}$} \\
\hline & German Government & EU & \\
\hline Decrease material waste & $\begin{array}{l}\text { BMU (1997: } \\
\text { Product stewardship } \\
\text { Management priorities: } \\
\text { Avoidance, recycling, } \\
\text { disposal. } \\
\text { Closed substance cycles. }\end{array}$ & $\begin{array}{l}\text { EAP (1992): } \\
\text { Efficient and sustainable } \\
\text { resource use. } \\
\text { Prevention of waste; } \\
\text { Recycling: waste treatment } \\
\text { with energy recovery, } \\
\text { incineration and deposition. } \\
\text { Recycling ratios of more } \\
\text { than } 50 \text { per cent for paper, } \\
\text { glass, plastics. } \\
\text { Waste production per capita } \\
\text { not beyond } 300 \mathrm{~kg} / \mathrm{cap} \text { in } \\
\text { each member state. }\end{array}$ & $\begin{array}{l}\text { SRU (1996): } \\
\text { Preference for material recycling. }\end{array}$ \\
\hline $\begin{array}{l}\text { Improve water resources, } \\
\text { water quality }\end{array}$ & Quality Class II in rivers ${ }^{1}$. & $\begin{array}{l}\text { EAP (1992): } \\
\text { Sustainable use of water } \\
\text { resources. }\end{array}$ & $\begin{array}{l}\text { SRU (1987): } \\
\text { At least a water quality of Class II } \\
\text { should be achieved in all water } \\
\text { resources. }\end{array}$ \\
\hline $\begin{array}{l}\text { Preserve forests and } \\
\text { fish resources }\end{array}$ & $\begin{array}{l}\text { BMU (1997): } \\
\text { Preservation of ecological } \\
\text { functions of forests. } \\
\text { Sustainable fisheries. }\end{array}$ & $\begin{array}{l}\text { EAP (1992): } \\
\text { Preservation of ecological } \\
\text { functions of forests. } \\
\text { Increased afforestation. }\end{array}$ & $\begin{array}{l}\text { UBA (1995): } \\
\text { Preservation of local, diversified } \\
\text { forests. }\end{array}$ \\
\hline $\begin{array}{l}\text { Preserve and restore soil } \\
\text { quality }\end{array}$ & $\begin{array}{l}\text { BMU (1997): } \\
\text { Minimisation of problematic } \\
\text { inputs. } \\
\text { Use of land with low impact } \\
\text { on ecology. }\end{array}$ & $\begin{array}{l}\text { EAP (1992): } \\
\text { Establishment of land use } \\
\text { planning for sensitive land } \\
\text { areas. }\end{array}$ & $\begin{array}{l}\text { UBA (1995): } \\
\text { Reduction of soil erosion to } 5 \text { to } \\
10 t / h a / a ; \text { in the long run } \\
\text { stabilisation of soils. } \\
\text { Wuppertal Institute (1995): } \\
\text { Reduction of soil erosion by } 80 \text { to } \\
90 \text { per cent in } 2010 \text {. }\end{array}$ \\
\hline
\end{tabular}

Note: for definitions and sources see glossary and bibliography.

1. Quality class II refers to water which is minimally polluted but suitable for human consumption and a wide range of aquatic life.

Source: OECD.

\subsection{Progress has been impressive although problems remain}

8. The improvement in environmental performance has been impressive over the last two decades. Remarkable progress has been made in reducing pollutants emitted from stationary sources (e.g. industrial and thermal power plants), such as sulphur dioxide $\left(\mathrm{SO}_{2}\right)$, particulates and some heavy metals, and large investments in municipal and in industrial waste water treatment plants have led to marked improvements in water quality. Thus by 1993, the OECD's Environmental Performance Review was able to conclude that Germany had been able to "decouple" economic growth from the flow of several major pollutants:

- Greenhouse gas emissions, carbon dioxide in particular, fell rapidly between 1990 and 1995 but this development was mainly due to the economic restructuring in the new Länder where emissions have been cut by almost one half (Tables 2 and 3). This special development can be mostly attributed to the process of de-industrialisation although new investment has also played a role by raising energy efficiency. Only traffic related emissions have been increasing strongly due to the catch up process in private car ownership. The most recent estimates indicate that carbon dioxide emissions for Germany have declined at a slower rate since 
1995, with increases in 1996 attributed to an abnormally cold winter (Figure 1). ${ }^{9}$ However, these figures are preliminary and need also to be interpreted in the light of a slower GDP growth since 1995.

- German water management policies have improved the quality of surface waters, especially in the old Länder. With a few exceptions, Quality Class II (broadly speaking, water suitable for human consumption) has been achieved in most rivers. The most important pollutants such as nitrates, heavy metals and hazardous substances (see Figure 2) etc. have been drastically reduced and ecological functions in many rivers have been restored. ${ }^{10}$ Remaining pollutant loads such as cadmium are very small and can hardly be controlled because they come from non-point sources and often occur as erosions from historic deposits ${ }^{11}$.

- Emissions of oxides of nitrogen and volatile organic compounds have fallen in the 1980s and 1990s.

\section{Table 2. Carbon dioxide emissions}

Million tonnes

\begin{tabular}{|c|c|c|c|c|c|c|c|c|c|}
\hline & \multicolumn{2}{|c|}{ Old Länder } & \multirow{2}{*}{$\begin{array}{c}\begin{array}{c}\text { Per cent } \\
\text { change }\end{array} \\
1990 / \\
1995\end{array}$} & \multicolumn{2}{|c|}{ New Länder } & \multirow{2}{*}{$\begin{array}{c}\begin{array}{c}\text { Per cent } \\
\text { change }\end{array} \\
1990 / \\
1995\end{array}$} & \multicolumn{2}{|c|}{ Germany } & \multirow{2}{*}{$\begin{array}{c}\begin{array}{c}\text { Per cent } \\
\text { change }\end{array} \\
1990 / \\
1995\end{array}$} \\
\hline & 1990 & 1995 & & 1990 & 1995 & & 1990 & 1995 & \\
\hline \multicolumn{10}{|l|}{ From incineration in } \\
\hline Energy production & 275.6 & 276.7 & 0.4 & 163.9 & 96.5 & -41.1 & 439.4 & 373.2 & -15.1 \\
\hline Industry & 120.7 & 111.5 & -7.6 & 49.0 & 15.3 & -68.7 & 169.7 & 126.8 & -25.3 \\
\hline Traffic & 138.8 & 144.6 & 4.1 & 19.8 & 26.2 & 32.1 & 158.6 & 170.7 & 7.6 \\
\hline Households & 138.8 & 157.2 & 13.3 & 59.4 & 28.8 & -51.5 & 198.2 & 186.1 & -6.1 \\
\hline Small enterprises & 45.5 & 41.4 & -9.0 & 24.3 & 9.5 & -60.8 & 69.8 & 50.9 & -27.1 \\
\hline Others (military etc.) & 12.9 & 10.2 & -21.2 & 7.7 & 2.3 & -70.7 & 20.6 & 12.5 & -39.6 \\
\hline Industrial processes & 22.0 & 22.0 & 0.2 & 5.6 & 3.2 & -42.5 & 27.5 & 25.2 & -8.4 \\
\hline International air traffic & 11.1 & 13.5 & 22.2 & 0.5 & 0.3 & -32.8 & 11.6 & 13.9 & 19.8 \\
\hline Total & 708.8 & 722.1 & 1.9 & 305.4 & 172.3 & -43.6 & 1014.2 & 894.5 & -11.8 \\
\hline
\end{tabular}

Source : Stein and Strobel (1997).

\section{9. $\quad$ DIW (1999a).}

10. For a summary of the rates of reduction of pollutants see OECD (1993). This process has continued and the water quality in surface waters in the new Länder is improving as well.

11. Klepper et al. 1995 a. 
Table 3. Emissions of greenhouse gases

\begin{tabular}{|c|c|c|c|c|c|}
\hline & 1990 & $1995^{1}$ & $\begin{array}{l}\text { Forecast for } \\
2005^{1}\end{array}$ & $\begin{array}{c}\text { Change } \\
1990 / 1995\end{array}$ & $\begin{array}{c}\text { Change } \\
1990 / 2005\end{array}$ \\
\hline & \multicolumn{3}{|c|}{ Megagrams } & \multicolumn{2}{|c|}{ Per cent } \\
\hline $\mathrm{CO}_{2}$ & $1025000 \times 10^{3}$ & $908300 \times 10^{3}$ & $883200 \times 10^{3}$ & -11 & -14 \\
\hline $\mathrm{CH}_{4}$ & 5682000 & 4788000 & 3004000 & -16 & -47 \\
\hline $\mathrm{N}_{2} \mathrm{O}$ & 226000 & 210000 & 159000 & -7 & -30 \\
\hline $\mathrm{CF}_{4}$ & 355 & 218 & 105 & -16 & -71 \\
\hline $\mathrm{C}_{2} \mathrm{~F}_{6}$ & 42 & 27 & 11 & -35.7 & -74 \\
\hline $\mathrm{SF}_{6}$ & 163 & 251 & 186 & +54 & +14 \\
\hline NMVOC & 3155000 & n.a. ${ }^{2}$ & 2700000 & n.a. & -14 \\
\hline $\mathrm{NO}_{\mathrm{x}}$ & 2640000 & n.a. & 2130000 & n.a. & -19 \\
\hline $\mathrm{CO}$ & 10742000 & n.a. & 5400000 & n.a. & -50 \\
\hline $\mathrm{H}-\mathrm{CFC}$ & 200 & 2214 & 7991 & +107 & +3896 \\
\hline
\end{tabular}

Note: $\quad$ Fr definitions, see glossary.

1. Including climate policy decided by 1996 .

Source : BMU (1997).

Figure 1. Carbon dioxide emissions ${ }^{1}$

Million tonnes

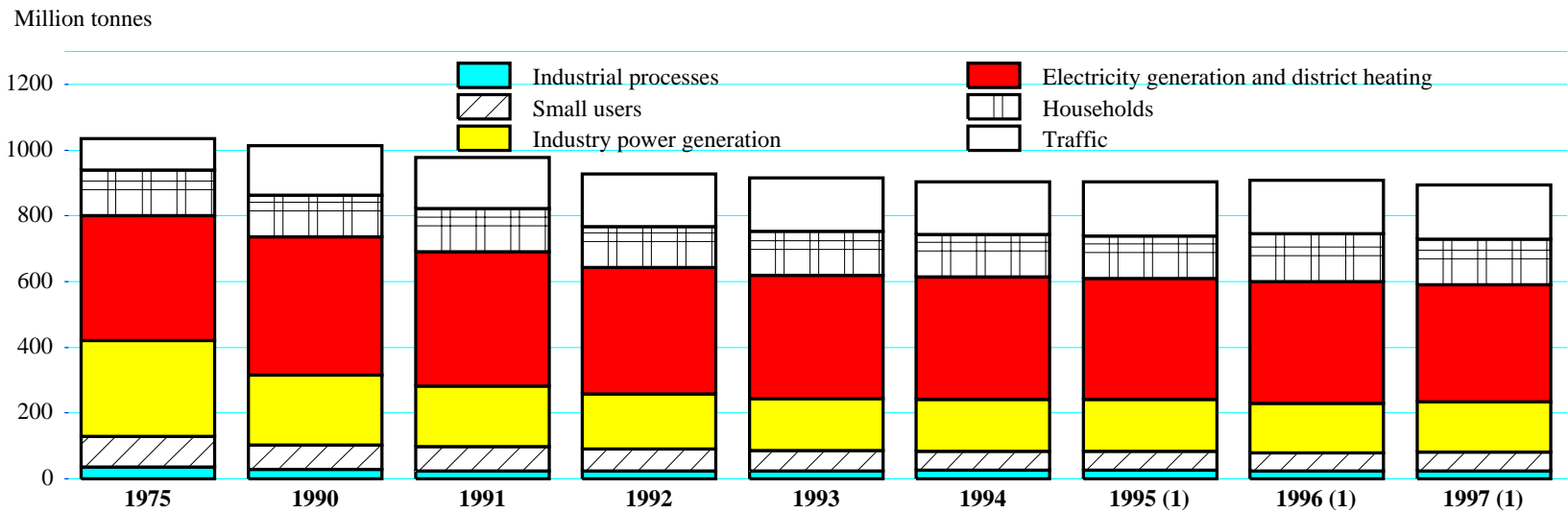

1. Total Germany from 1991.

2. Provisional data (December 1998).

Source: Bundesministerium für Wirtschaft un Technologie (BMWi). 


\title{
Figure 2. Heavy metal concentrations in the Rhine at the Dutch border ${ }^{1}$
}

\author{
Level of concentrations $1971-1975=100$
}

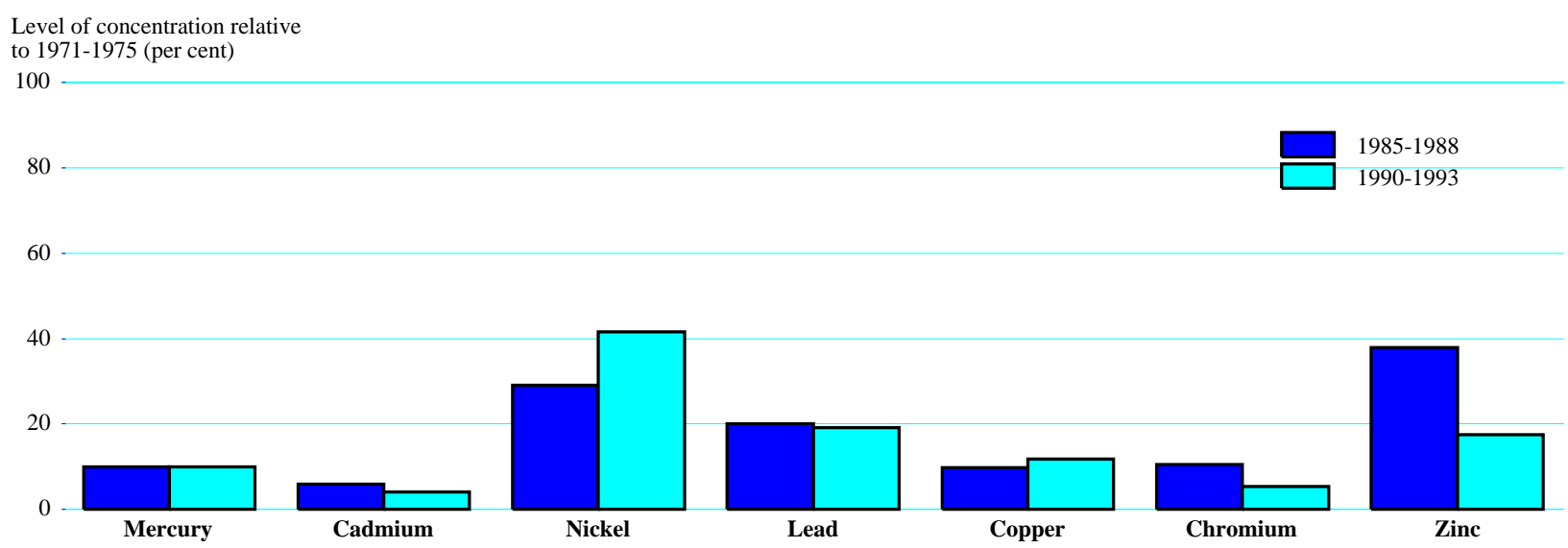

1. Expressed in $\mathrm{mg} / \mathrm{kg}$. Concentrations in the Elbe have been reduced by similar percentages but the initial pollution was much higher so that improvements are still necessary to reach the absolute levels comparable to the Rhine. Source: Bundesumweltministerium (BMU).

9. Despite these advances, achieving environmental goals is proving to be difficult in a number of areas:

- Estimates of carbon dioxide emissions up to the year 2005 indicate that, taking account of all policy decisions made up to the year 1996, Germany is likely to fall short of its target emission level by a large margin (Annex I). Subsequent policy initiatives, including the energy tax, which became effective in April 1999, have not been sufficient to alter this conclusion significantly. ${ }^{12}$

- Emissions of nitrogen oxides $\left(\mathrm{NO}_{\mathrm{x}}\right)$ and volatile organic compounds, having fallen in the 1980s and 1990s, are expected to increase again (Annex I). Emissions of both are considered too high contributing to forest damage and to summer smog in urban areas (Box 1).

- Point sources of pollution in surface waters have been effectively brought under control, but non-specific sources remain a problem: about 60 per cent of the nitrogen load in rivers originates from such sources even though there is some tendency for improvement. A large proportion is due to run-offs from agriculture, from drainage and from erosion, as well as, most importantly, groundwater contamination (Table 4). This pollution load from non-point sources apparently requires further and different policy initiatives.

- Although nitrogen emissions were reduced by about a quarter between 1985 and 1995, this fell well short of the 50 per cent reduction requirement demanded by the Third North Sea Conference in 1990. The coastal areas in the North and on the Baltic Sea receive pollutants from rivers, as well as through the air. The nutrient load from rivers and from direct discharges into the sea continue to add to eutrophication problems especially in the Baltic

12. The environmental effect of the energy tax is considered by most observers to be small, one study reporting an optimistic scenario of at most a 2 per cent further reduction in carbon dioxide emissions. ZEW (1999). Moreover, estimates of the environmental impact from the planned increases of the energy tax rate in the period 2000 to 2003 are also small. RWI (1999b). 
Sea. The main nutrient loads come from agriculture and sewage plants, while for other pollutants, the main sources include air traffic and power stations.

10. In sum, with respect to environmental quality, significant progress has been achieved in many areas, and projections show important improvements in comparison with the status quo ante. However, significant slippage from some policy targets is apparent, for example, carbon dioxide emissions and nitrate pollution in rivers. In other areas the targets, even if achieved, could be insufficient to meet environmental goals with respect to urban air pollution and forest preservation. Moreover, further challenges need to be faced: the intention to close nuclear reactors eventually must make, inter alia, carbon dioxide reduction targets more difficult to achieve, while national targets will need to be further tightened in the decades ahead if the global concentration of carbon dioxide is to be stabilised (OECD 1999a). These environmental policy issues raise questions which go beyond simply tightening existing policies: how should policies and targets be formulated in the most cost effective manner? The question involves not only issues of economic principle but also ones of institutional, legal and political arrangements since at the end of the day, judgements about the benefits of environmental targets -- and often about the costs involved -- are highly subjective.

\section{Box 1. Despite lower levels of pollution, damage to forests has not been reduced significantly}

The damage to forests (Waldschäden) has been monitored since 1984, when the problem was already widespread with half of all trees showing symptoms of environmental stress. Until the early 1990s, the proportion of trees without any damage (category 0 ) was falling and that of trees with significant and severe damages (categories 2 and 3), and dead trees (category 4) was increasing. Since 1991, data for unified Germany show a decrease in damage. However, this is mainly due to a significant improvement in the new Länder, where apparently the immediate emission impact on trees has been reduced due to the closing down of industrial emission sources, a strong reduction in the use of brown coal in domestic heating, and modernisation of the capital stock. In the old Länder damage is still rising in some states, mostly in the north-western part of the country.

Complex chemical reactions between different pollutants subject to sunlight contributes to forest damage. The most important pollutants are sulphur dioxide $\left(\mathrm{SO}_{2}\right)$, nitrogen oxides $\left(\mathrm{NO}_{\mathrm{x}}\right)$, ammonia $\left(\mathrm{NH}_{3}\right)$, and ozone $\left(\mathrm{O}_{3}\right)$. In combination, they damage trees directly by reducing the functions of leaves, or by accumulating substances in the soil which then lead to long-run damage of the roots. These substances are removed from soils only slowly, so that a reduction in emissions will only result in a very gradual diminution of damage from contaminated soils. ${ }^{1}$ Despite the emission reductions achieved so far, the deposit levels in forests remain too high. Acidification and eutrophication, through sulphur and nitrogen emissions, remain the major contributors to damage. According to the German government, in 1993 only 16 per cent of the forest area was subject to acidifying depositions below the critical load; for nitrogen eutrophication, only 5 per cent of the forest area is below the critical level. ${ }^{2}$ Although emission reductions from national and foreign sources have, been significant, harmful effects of pollutants accumulated in the soil are long lasting. ${ }^{3}$

1. BML (1996b), (1997).

2. BML (1997).

3. For the year 2005 a further reduction to 0.26 million tonnes of dust, to about 0.55 million tonnes of $\mathrm{SO}_{2}$, to 1.74 million tonnes of NMVOC (see glossary) are expected. The reduction of nitrogen oxides $\left(\mathrm{NO}_{x}\right)$ is only expected to reach 2.14 million tonnes in 2005 (BML, 1997). 


\section{Table 4. Nitrogen emissions into rivers}

1995

\begin{tabular}{|c|c|c|c|c|c|}
\hline & $\begin{array}{l}\text { Thousand } \\
\text { tonnes }\end{array}$ & Per cent & & $\begin{array}{l}\text { Thousand } \\
\text { tonnes }\end{array}$ & Per cent \\
\hline $\begin{array}{l}\text { Non-point sources } \\
\text { of which: }\end{array}$ & 460 & 60 & $\begin{array}{l}\text { Point sources } \\
\text { of which: }\end{array}$ & 315 & 40 \\
\hline Precipitation & 20 & 3 & Industry & 60 & 7 \\
\hline Agricultural run-off & 20 & 3 & Treated rain water & 20 & 3 \\
\hline Drainage & 45 & 6 & Waste water from & & \\
\hline Erosion & 45 & 6 & Households & 235 & 30 \\
\hline Ground water $^{1}$ & 330 & 42 & & & \\
\hline
\end{tabular}

1. 90 per cent of which from agricultural sources.

Source: BMWI (1996).

\section{The framework of policy formation}

\subsection{Regulations versus economic instruments}

\subsubsection{The cost-effectiveness of environmental policies}

11. A consistent theme of the discussion below is whether the benefits of environmental policies, in terms of improved environmental performance, have been achieved in a cost-effective manner. On the one hand, the rationale for government intervention is clear: the social costs of economic activity are not taken fully into account in current relative pricing -- transport is one example, coal-fired energy consumption is another. In principle, the economic answer would be to incorporate social externalities into prices, and attempt to reach the "right" level of environmental quality (or pollution) at lowest cost by equalising the marginal (aggregate) damage to marginal abatement costs. This would ensure both that polluters pay in proportion to the damage they cause and that resource allocation was based on decisions where environmental consequences were fully taken into account. But, on the other hand, such externalities may be difficult to measure -- indeed, the concept of marginal damage is far too static for a situation where "sustainable development" could be threatened by cumulative environmental damage. And incorporating social externalities into prices might have important short-run costs in terms of economic dislocation. In practice, therefore, as the discussion below indicates, the setting of specific targets and objectives for environmental policy has taken place mainly through the political process, involving most interest groups in the economy. The process is not an explicit one since even at the project level -- with the exception of some transport projects -- formal cost-benefit analysis has played very little role compared with legal and regulatory considerations, of the administrative courts in particular. ${ }^{13}$ The policy issue which needs to be considered is whether the process has effectively related the benefits of environmental policy to the costs.

12. Nevertheless, even where policies addressing specific environmental problems are not optimal in the sense of being allocationally efficient, they can be made individually cost-effective. Cost minimisation requires solely that the marginal abatement cost from all sources of pollutants or emissions is equalised. If it is not, resources could be diverted from sectors and activities where it is relatively costly to comply, offering potential efficiency gains. This is particularly important in Germany where environmental policies cover a wide range of sectors and activities (Table 5), each of which might be associated with differing marginal costs of abatement, including monitoring costs. Indeed, even within broadly defined sectors,

13. Jänicke and Weidner, 1997. 
marginal abatement costs could differ widely between plants and industrial processes. The instruments being used to achieve environmental targets being mainly regulatory, they have been highly specific to each sector and even to individual processes. The issue is whether there is an integrating system which takes into account the time-varying abatement costs in other sectors or sources of emissions. Without this process, advances in environmental performance might be largely borne by particular sectors and activities which are easy to regulate or control but not necessarily those associated with the lowest marginal cost.

Table 5. Key environmental targets and economic activities

\begin{tabular}{|c|c|c|c|c|c|}
\hline $\begin{array}{l}\text { Economic sectors or } \\
\text { activity involved }\end{array}$ & $\begin{array}{c}\mathrm{CO}_{2} \text { and } \\
\text { climate change } \\
\text { gases }\end{array}$ & $\begin{array}{l}\text { Air pollution } \\
\text { including } \mathrm{SO}_{x} \\
\text { and } \mathrm{NO}_{x} \\
\text { emissions }\end{array}$ & Water & Soil & Biodiversity \\
\hline Agriculture & $\star *$ & * & $\star * *$ & $* * *$ & $* * * *$ \\
\hline Consumption/household & $* * *$ & * & * & & $* *$ \\
\hline Industry & $* * *$ & $* * *$ & ** & & * \\
\hline Energy generation & $* * *$ & $* * *$ & * & & ** \\
\hline Transport & $* * *$ & $* * *$ & & & ** \\
\hline Waste disposal & $* * *$ & $\star *$ & $* * *$ & $* * *$ & * \\
\hline Imported & & ** & $\star \star$ & * & \\
\hline
\end{tabular}

Note: Illustrative level of importance ${ }^{* \star *}=$ highly important; ${ }^{*}=$ less important.

Source : OECD.

13. In theory, regulations could be designed so as to achieve an efficient outcome, but the necessary information to achieve this is rarely available. In the German case, as will be seen below, regulations have been implemented in close consultation with polluters and have often been so differentiated that marked variations in marginal abatement costs across sectors and sources might have been avoided. Such an outcome can be facilitated where many of the actions implemented belong either to "no-regret" strategies or to policies implemented in an environment where marginal abatement costs are in any case low. Several German studies ${ }^{14}$ have found that resources may not be used efficiently, due to a lack of information, education, or institutional/market failures. In this case, environmental policy measures can be introduced without imposing welfare costs on the economy resulting in a "win-win" situation. Such "no-regret" options can be realised where the actors concerned receive information about the profitability of such actions or where, for example, best technology has already been discovered by others and is now enforced by regulation. The implications are that information policies may make an important contribution to reducing the marginal costs of pollution reduction: carbon-dioxide emissions are a case in point, where until 1997 cuts were relatively easy to make (see below). Voluntary agreements are usually predicated on the assumption that certain anti-pollution gains are easy to make and that the sharing of information is important.

14. The Umweltbundesamt has conducted several ex post cost-benefit studies of environmental policies and concluded that the returns from environmental protection (the ratio of costs to overall benefits) ranged from 1:1.5 for noise abatement to 1:20 in the case of desulphurisation of power stations, depending on the instruments chosen. ${ }^{15}$ High rates of return might indicate a period where "no regret" measures were

14. Enquete-Commission 1995, Deutscher Bundestag 1997.

15. It is not clear how externalities have been valued and whether they are consistent between studies. BMU, (1998c). 
possible or where marginal abatement costs were low. The above studies do not, however, shed light on whether the most cost-effective instruments were in fact adopted (i.e. whether the same goals could have been achieved at even lower cost) and whether costs for the economy as a whole have been minimised. Moreover, even where regulations have been cost effective, the prospects both of higher marginal abatement costs in the future and of a tightening of environmental targets have focused attention on the correct balance between regulation and economic instruments, such as ecological taxes and/or tradable emissions permits to achieve future environmental goals. Under such circumstances, regulations could need to be adapted and co-ordinated and greater emphasis given to policies which make greater use of economic instruments to achieve an equalisation of abatement costs. Economic instruments are not a complete substitute for regulation; indeed, there is often strong complementarities. However, the regulatory system does need to be compatible with a greater use of economic instruments where these are appropriate.

\subsubsection{Links to economic objectives}

15. In allocating to economic instruments a larger role in meeting environmental targets, the issue of efficient markets comes to the fore. Thus far, subsidies and tax exemptions (for car-transport expenditures, subsidisation of agriculture and coal-mining etc.) and competition-inhibiting regulations have been used to try to meet employment and competitiveness objectives while often ignoring any environmentally harmful side-effects. There have thus been inconsistencies between macroeconomic policy objectives and ecological ones. In moving ahead towards a more cost-efficient environmental policy, clearer and more consistent objectives will be required across all public programmes. Instruments which are targeted toward the source of emission or environmental damage can only be effective in markets where there are proper economic incentives and adequate price signals. In this sense, economic and environmental efficiency are mutually reinforcing. Indeed, where competition is constrained and individual markets are distorted by regulation and government intervention, economic instruments such as ecological taxes cannot be clearly focused and there is a danger that policy may risk falling short with respect to both economic and ecological objectives.

16. In the process of shaping ecological instruments to meet economic as well as environmental goals, attention in Germany has turned to the specific proposition that the revenues from ecological taxes can be used to achieve higher employment by reducing the tax burden on labour (and by raising the relative price of the environment). Fundamental to the strategy of the government is the judgement that there is a potential for a "double dividend". Two studies ("DIW/Greenpeace Study" and the IEW study) find strong positive employment effects from such a policy. Other studies are less sanguine about positive employment effects and the possibility of a "double dividend". A broader study, which looks at German environmental policy in a European context and examines the role of policy co-ordination, finds some potential for a double dividend in the EU; but there are numerous uncertain influences which might alter the sign of the welfare effect. Employment could rise but not to any great extent and not by enough to solve the unemployment problem. By contrast, two other studies come to the opposite conclusion: that an ecological tax increases the unemployment rate. The analyses undertaken relate to different types and levels of efficiently designed environmental taxes and it is worth noting that the implied carbon dioxide tax is often high (as are the revenues), a result confirmed with the OECD Green model.

17. The "double dividend" controversy, which revolves, in essence, around whether a move to ecological taxes (which are borne partly by inactive members of the population) can shift the incidence of taxation away from labour, illustrates the extent to which environmental policy effectiveness depends upon a policy setting which is not distorted by non-environmental sectoral considerations. Environmental effects and economic benefits will be the more significant where marginal-abatement costs are equalised, as discussed above, which requires a non-discriminatory approach. In this respect, attempting to graft a sectorally-focused ecological tax regime (i.e. one that differentiates rates among polluters and emissions) 
onto a selective regulatory system would tend to reduce the possibility of a double dividend occurring. The following discussion, which tracks German environmental policies through from the creation of a complex regulatory system to the introduction of the energy tax system in April 1999, is based on the proposition that achieving a significant "double dividend", in terms of both employment and environmental performance, depends on the evolution towards a broad-based and mutually consistent approach to the use of economic instruments.

\subsection{Implications of a federal institutional structure}

18. The institutional framework has exercised a powerful influence in the setting of policy objectives and targets, as well as in the choice of instruments, and proposals for future policy directions need to take the factor into account. Germany is a federal state, with the power to determine environmental policies divided among the federal, state (Länder), and local authorities. Following an amendment to the German constitution, the federal government has obtained "concurrent" legislative power in the areas of waste management, air pollution control, noise abatement, protection from radiation, and criminal law related to environmental protection matters. In these policy areas federal regulations supersede state and local decisions. In the case of water management, regional planning, nature conservation and landscape preservation, the federal government can only issue so-called framework laws, which oblige state governments to pass supporting legislation. Federal legislation and ordinances may, in turn, be constrained by minimum standards defined at the European level if such requirements exist. In those cases in which the federal government has only "framework competence", co-ordination and subsequent legislation at the Länder level is necessary. The Länder legislation often defines the framework in which local authorities implement environmental policies. Especially in those cases where direct regulatory instruments are used, substantial discretion remains at the local level.

19. Within the federal government, resource and environmental policies are not exclusively assigned to the Federal Ministry for the Environment. This is, in part, due to the fact that resource or environmental policies have historically been allocated to ministries within whose domain such policies impacted. For example, in the case of water management, drinking water quality and supply policies are dealt with in the Ministry of Health, while water management in the rural sector, as well as flood protection and coastal zones management, is in the responsibility of the Ministry of Food, Agriculture and Forestry. Waterways are managed by the Ministry of Transport and energy policy is under the auspices of the Economics Ministry. Such an allocation of responsibilities may enhance the co-ordination between environmental and other policy objectives, but it requires intense efforts to achieve consistency between environmental policy instruments in different areas. Each Ministry has its own environmental group and there is a dense network of inter-Ministerial Committees although how co-ordination works in practice is unclear. Co-ordination might be improved by underpinning decisions through formal cost/benefit or cost effectiveness analysis.

\subsection{Influence of EU regulations}

20. Community-wide environmental regulations in the EU increasingly both stimulate and constrain the ability of the federal and the Länder legislatures in formulating their environmental policies. In the case of air pollution, minimum ambient air quality standards for several substances $\left(\mathrm{SO}_{2}, \mathrm{VOC}, \mathrm{Lead}, \mathrm{NO}_{\mathrm{x}}\right)$ have been the subject of several directives. ${ }^{16}$ Although the management of water resources and water quality contains local as well as trans-frontier aspects, the European Commission issued several directives on the preservation of water resources as early as 1972. Ambient quality standards have been set for many types of water resources, including monitoring and information requirements for national governments, which effectively limits the principle of subsidiarity. One of the major concerns of the European

16. The European regulation of emissions from large combustion facilities was based on the German Ordinance, illustrating the possibility for some large countries to lead by setting tough standards. 
Commission is the possibility that national environmental regulations may limit the free movement of goods in the internal market. For example, in the case of waste management policies, Germany has been criticised for choosing waste policies which could create barriers to entry for foreign suppliers of consumer goods. ${ }^{17}$ Similarly, the scope for structuring energy taxes is constrained by the need not to discriminate, directly or indirectly, against energy imports from other member countries. ${ }^{18}$

21. The EU framework tends to favour regulatory instruments and minimum standards (Box 2) and forecloses a number of policy options. Regulations and directives are often preferred because the competence of the Commission is more easily exercised in this area than that of taxation, and decisions require a simple majority. But majority voting also makes it unlikely that very restrictive standards are adopted. On the other hand, EU-wide economic instruments such as environmental taxes require unanimous voting which in a community characterised by widely different interests makes it less likely that they will be adopted. The failure to reach agreement on the Commission's carbon dioxide/energy tax proposal is a case in point.

\section{Box 2. The role of the $\mathbf{E U}$ in environmental policy}

The European Community now has an important influence in defining the options for and the implementation of environmental policy in Germany. At the end of 1997, 212 directives, 43 regulations and 77 decisions of the EU were in force. ${ }^{1}$ Until 1987, EU environmental policy had no explicit legal foundation, so that measures were based on internal free market requirements. However, since the Amsterdam Treaty entered into force in 1997, the EU has at its disposal several means for policy intervention: the common environmental policy, single market policy and common policies with side effects on environmental issues. Each mechanism involves different decision making processes, including different powers for the EU parliament.

The common environmental policy recognises the importance of sustainability and is subject to the subsidiarity principle. The parliament has co-decision making powers. Decisions covering taxes such as a carbon dioxide tax and national energy supply are exceptions and can only be decided unanimously. Member states are allowed to adopt stricter measures but these have to be notified to the Commission. The Commission has moved to specify national minimum standards (such as for water quality and energy taxes), which serve to restrict the principle of subsidiarity.

Single market based environmental policy is made on a qualified majority voting basis and in co-decision with the European parliament. Individual countries are allowed to retain or adopt stricter standards if these do not restrict trade between EU members and if they are based on new scientific information or on specific country problems. However, the Commission decides on the legitimacy of the standards, so that the possibility for countries to react to national problems is in practice restricted. Community policy competencies are not limited by explicitly specified supra-national environmental problems.

Common policies in areas such as transport, agriculture, energy and regional development have to take into account the requirement of environmental protection, especially the aim of sustainability. However, majority voting in some cases, and unanimity in others can weaken this mechanism, especially if environmental objectives would call for fundamental changes in sectoral policy approaches such as in agriculture.

1. Welfens and Hillebrand (1998).

17. The quotas for refillable containers in the packaging ordinance or the planned prohibition of sales of mineral water in one-way bottles (which has been withdrawn) are just two examples. The voluntary takeback guarantee for used cars has also been criticised by foreign car-makers as discriminatory for manufacturers not located in Germany.

18. For example, Finland had a carbon tax but to protect local electricity generators they imposed an import tax for electricity. This was ruled to be out of line with EU regulations. See OECD Economic Survey of Finland, 1999. 


\subsection{A complex regulatory structure}

22. The effects of the above institutional structures have been to create a highly complex regulatory system with minimal use of economic instruments. There is no single environmental code in Germany (Umweltgesetzbuch), but rather a tangle of laws and regulations which are sometimes inconsistent. The initial emphasis on public health, which coincided with a strong belief in state control and in social planning, led to legal and regulatory measures which increased in complexity over time as new issues were identified and handled individually. This also tended to lead to an emphasis on sector specific policies, such as those focused on power plants, rather than on policies aimed at emissions from all sources, or at the cause of environmental problems more generally. Many environmental policies (air pollution control, many water quality policies) rely on a direct regulation of emissions. The laws and directives involved often require best available technologies to be used in a particular plant. The local regulatory agency now has only limited discretion in deciding which abatement activities are appropriate. To be economically efficient, direct regulation requires considerable co-ordination vertically and horizontally among government agencies, which in practice is scarcely possible. Co-ordination issues are reduced by economic instruments.

23. In formulating specific policies and targets, three basic principles have been utilised: precautionary action; co-operation, and the "polluter-pays". The precautionary principle has been a key element since1971, when the federal environment programme was updated. It is important since it has been interpreted as requiring the ex ante regulation of potential emission sources. This has, in turn, led to regulation which specifies (requires) best available technologies in terms of emission prevention, at the end-of-pipe stage as well as in the integrated production processes. Emission standards are also based on this principle. The second principle, of co-operation, requires a policy approach that emphasises consensus between the affected parties, especially the emitter and the regulating agency. The third principle, that the "polluter pays", has been interpreted along the lines of the OECD as meaning that the cost of avoiding or remedying environmental pollution must be borne by the "party responsible for its occurrence". ${ }^{19}$ The principle has been applied in so far that emitters are obliged to pay for the cost of the technology or other actions demanded by the regulator but the coverage is not complete. For instance, Germany has adopted a number of direct and indirect subsidies to promote environmentally-sound practices in the private sector, especially in agriculture (see below). However, the polluter-pays principle is rather limited in that there is no requirement to compensate society as a whole for the damage imposed by an emitter from ongoing pollution.

24. A resulting key feature of the institutional setting is the role assigned to voluntary agreements and the generally close relations between polluters and the regulatory authorities, both of which stem from the emphasis on co-operation in determining policy. Voluntary agreements (Box 3) cover areas as diverse as carbon dioxide reduction by industry, the phasing out of fluorocarbons, taking back of batteries and the disposal of old cars. ${ }^{20}$ Indeed, the law covering waste disposal foresees voluntary agreements and the EU has also recommended their adoption. In addition, voluntary agreements are also being used to promote clean technologies such as agreements on the reduction of car fuel consumption and the promotion of the three litre/100 Km car. The availability of this close negotiating mechanism has limited policy options (see below) and may account for the hostility shown by industry to environmental taxes which need to be approved by the parliament and might thus be vulnerable to more general fiscal pressures.

19. $\quad$ BMU (1997), p. 8.

20. Rennings et al., 1997. 


\section{Box 3. Voluntary agreements/arrangements in environmental policy}

Voluntary agreements have been used extensively in Germany to implement environmental policy especially with respect to climate change and waste disposal: there are some 100 such agreements and only the Netherlands has anywhere near this number of agreements in OECD Europe. 'The agreements have been negotiated between industry associations and the government and usually concern the specification of pollution abatement objectives (i.e. they are target-based). However, in the waste sector there are also implementation-based agreements, which specify measures to achieve targets set by legislation. In Germany the agreements are not legally binding since the government has no legal powers to sign agreements with associations. However, there has often been a threat of additional regulatory action in the event of no agreement or if its aims are not achieved.

The motivation for the government in seeking voluntary agreements include the desire to hold down implementation costs and to preserve international competitiveness. They are also viewed as useful in new areas of environmental policy where laws and regulations are still untried. Moreover, co-operation between government and industry has a long history. For industry associations such agreements offer the prospect of raising flexibility in comparison with regulation. There may also be significant "soft effects" in terms of dissemination of information and awareness raising.

There are also significant negative features associated with such agreements. Agreements which set environmental targets are not likely to be ambitious and exclude the interests of other members of society. Indeed the OECD has concluded that their environmental effectiveness is generally low. This conclusion is also applicable for Germany. For example, the agreement to reduce fuel consumption of cars roughly corresponds to what in any case appears to be the trend while the agreement with industry to lower $\mathrm{CO}_{2}$ emissions appears to set objectives below the business as usual path. The agreement to take back old cars free is also of little ambition since the cars involved still have a market value (see below). ${ }^{2}$ In other cases discussed in this paper, voluntary agreements can be used as a barrier to entry against new rivals thereby reducing competition and welfare. Agreements often attribute identical targets to individual firms rather than concentrating abatement where costs are lowest. This reduces their cost effectiveness relative to the use of economic instruments.

1. See Voluntary Approaches for Environmental Policy In OECD Countries: An Assessment, OECD, Paris, 1999.

2. K. Rennings et al., "Voluntary Agreements in Environmental Protection: Experience in Germany and Future Perspectives", Business Strategy and the Environment, 6, 1997.

\subsection{Public outlays}

25. Environmental policy has involved significant outlays, although individual indicators should be treated with care. Pollution abatement and control expenditure in the old Länder as a share of GDP is around $1 \frac{1}{2}$ per cent and is rather high among OECD countries (Table 6) while the capital stock devoted to environmental protection is now also significant (Table 7). However these expenditures refer only to end-of-pipe costs ("additional" costs) and not to equipment integrated into production processes to reduce emissions or to lower consumption of resources. More importantly, they exclude the significant expenditures which have been undertaken to improve environmental performance in the new Länder. The volume of expenditures in the new states is not known with certainty and many projects have been undertaken in conjunction with work-creation schemes which has served to raise costs. In addition to the re-equipment of power plants and the installation of water purification facilities -- both of which have led to significantly higher user charges in the east than in the west --, significant expenditures have been devoted to the rehabilitation of polluted industrial and military sites. ${ }^{21}$ Whether these projects made sense

21. Two examples give an indication of the size of the task. In the lignite mining area, more than 160 open cast pits needed levelling, 38500 dumping grounds were in need of rehabilitation and 750 deposits of industrial waste had to be treated. Up to 1996, 20000 hectares of land had been rendered reusable and 390 million trees had been planted. From 1993 to 1997 some DM 7.1 billion and for 1998 to 2002 some DM 6 billion 
in terms of meeting environmental objectives in a cost effective manner or whether they were primarily driven by local labour market conditions is unclear. An indication of the total outlays involved in both the new and the old Länder can be gained from employment statistics: a joint survey published in 1996 by the four leading economic institutes concluded that some 956000 people were employed in environmental protection in 1994, about 2.7 per cent of the workforce or nearly the same share as vehicle manufacturing. ${ }^{22}$

\section{Table 6. Environmental expenditure on pollution abatement and control} Per cent of GDP, mid-1990s or latest available year ${ }^{1,2}$

\begin{tabular}{|c|c|c|}
\hline & Public and private sectors & Public sector only \\
\hline United States & 1.6 & 0.7 \\
\hline$J^{\prime a p a n^{3}}$ & 1.1 & 0.9 \\
\hline Germany (western) ${ }^{4}$ & 1.4 & 0.8 \\
\hline France & 1.4 & 1.0 \\
\hline Italy & 0.9 & 0.5 \\
\hline United Kingdom & 0.3 & 0.4 \\
\hline Canada & 1.1 & 0.7 \\
\hline Australia & 0.9 & 0.6 \\
\hline Austria $^{4}$ & 1.7 & 1.0 \\
\hline Denmark & 0.9 & 0.6 \\
\hline Finland $^{5}$ & 1.1 & 0.6 \\
\hline Greece & 0.8 & 0.5 \\
\hline Hungary & 0.7 & 0.3 \\
\hline Iceland &.. & 0.3 \\
\hline Netherlands & 1.8 & 1.3 \\
\hline Norway $^{6}$ & 1.2 & \\
\hline Poland & 1.2 & 0.3 \\
\hline Portugal & 0.7 & 0.6 \\
\hline Spain & 0.5 & 0.5 \\
\hline Sweden & 1.2 & 0.8 \\
\hline Switzerland & 1.6 & 1.0 \\
\hline
\end{tabular}

1. Figures are not necessarily comparable, since methodologies and coverage differ across countries.

2. Data coverage across countries differs from year to year. In general, changes have been rather modest in the time period covered (1985-97); with some exceptions (which could be the result of changed data coverage, etc., and not necessarily changes in PAC expenditures).

3. Data on business sector current expenditure not available.

4. These data are not comparable with other data because the definitions and methodology used are different. The OECD estimate for public and private sector PAC expenditure is 1.7 per cent of GDP.

5. Includes an estimate for public sector PAC expenditure.

6. OECD estimates for 1990.

Source: OECD, Environmental Indicators, 1998.

of funding has been made available. In the case of the uranium mining and industrial complex at Wismut some DM 13 billion has been made available for rehabilitation.

22. Employment in environmental protection is often put forward not as an indicator of cost but as an indicator of collateral benefits from environmental policy. DIW et al., 1996. This is not appropriate and confuses labour market issues with questions of foregone income from environmental policy measures. In effect labour is being valued at zero opportunity cost. 
Table 7. Expenditure on environmental protection in the old Länder

In DM billion (in nominal prices)

\begin{tabular}{lrrrrrr}
\hline & 1975 & 1980 & 1985 & 1990 & 1994 & 1995 \\
\cline { 2 - 6 } & 72 & 124 & 165 & 220 & 305 & 316 \\
$\begin{array}{l}\text { Environmental protection assets, government-owned } \\
\begin{array}{l}\text { Environmental protection assets belonging to } \\
\quad \text { the manufacturing industry }\end{array}\end{array}$ & 22 & 35 & 51 & 83 & 105 & 107 \\
$\begin{array}{l}\text { Environmental protection investments by the } \\
\quad \text { Government }\end{array}$ & 4.7 & 8.1 & 6.8 & 10.4 & 10.8 & 10.6 \\
$\begin{array}{l}\text { Environmental protection investments by the } \\
\quad \text { Manufacturing industry }\end{array}$ & 2.5 & 2.7 & 5.6 & 7.2 & 4.8 & 4.2 \\
$\begin{array}{l}\text { Current environmental expenditure by the } \\
\quad \text { Government }\end{array}$ & 3.0 & 4.7 & 6.4 & 9.3 & 13.5 & 13.5 \\
$\begin{array}{l}\text { Current environmental expenditure by the } \\
\quad \text { Manufacturing industry }\end{array}$ & 3.2 & 5.2 & 7.9 & 11.2 & 14.0 & 14.8 \\
Environmental expenditure as a proportion of GDP & 1.3 & 1.4 & 1.5 & 1.6 & 1.5 & 1.4 \\
\hline
\end{tabular}

1. Publicly-owned environmental assets, 1995: 91 per cent water protection, 7 per cent waste disposal.

2. Privately-owned environmental assets, 1995: 55 per cent water protection, 29 per cent waste disposal.

Source: 1998 Report on the Environment, BMU (1998).

\section{Policies in force and directions for change}

26. With the economic consequences of environmental policy in mind, it is useful to separate the instruments currently applied into five categories:

- Regulations, laws, guidelines, such as emission related laws and ordinances;

- Economic instruments, including energy taxes and subsidies for alternative energy sources, tax exemptions, subsidised loans, public infrastructure investments, and funding of research and development

- Voluntary agreements by which the business sector, such as automobile producers, agree to meet specific environmental objectives;

- Information, education and training, to raise the awareness of the German public about environmental policy;

- Research and development, including interdisciplinary approaches to climate impact research, energy saving technologies etc.

Of these instruments, direct regulations and voluntary agreements rely on non-market mechanisms; hence, the possibility of using relative price signals is largely non-existent. However, as regulatory intervention becomes more costly, especially as the scope for "no-regret" policies or low abatement cost opportunities are used up, the current policy configuration may have to give way to a different policy mix. 
Figure 3. National indicators of progress toward sustainable development

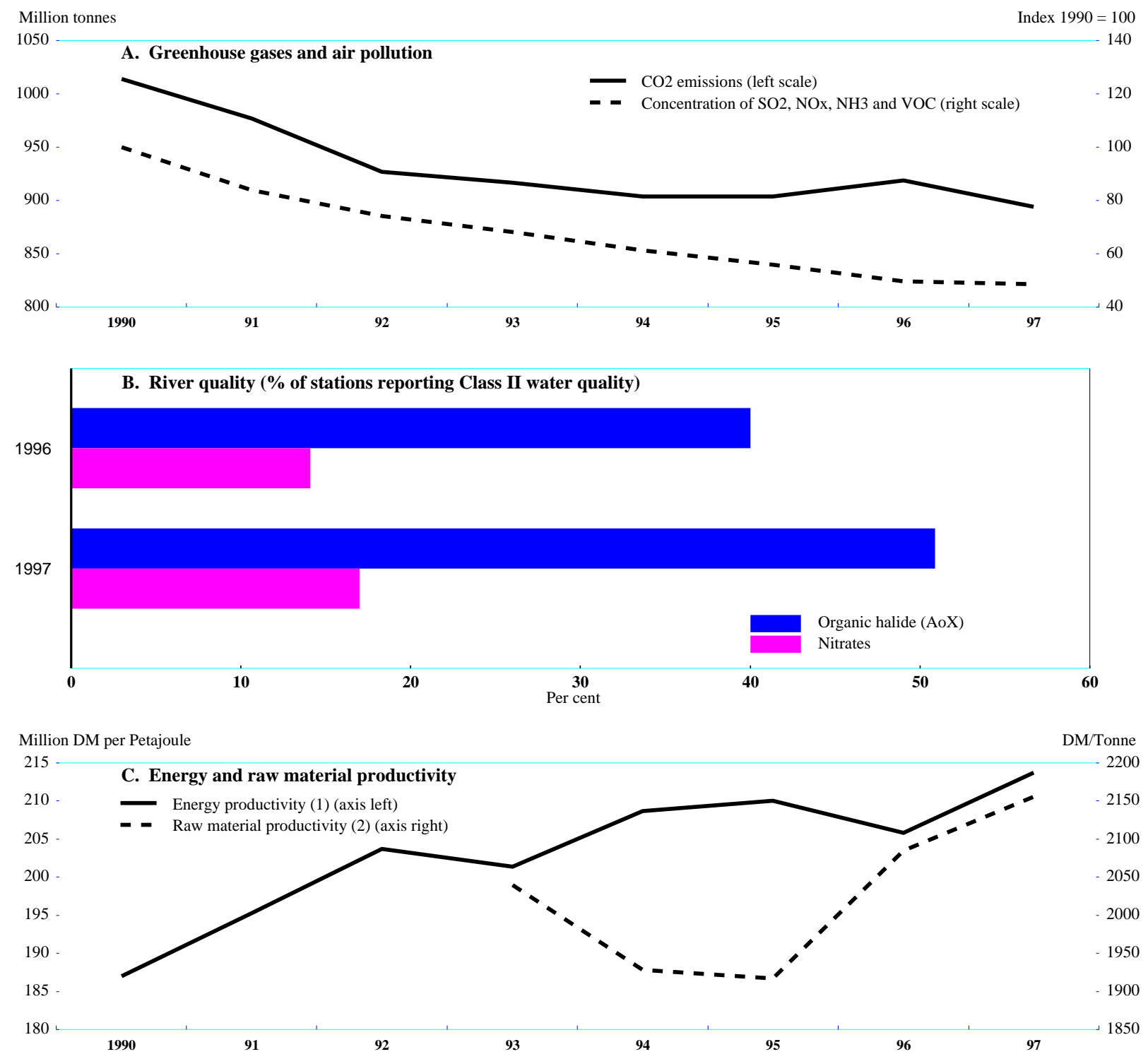

1. Defined as the ratio of GDP at 1991 constant prices to primary energy supply (expressed in Petajoule).

2. Defined as the ratio of GDP at 1991 constant prices to national extraction of raw materials (mineral, clays, etc.) and imports of goods (raw materials, half-finished goods, finished goods). All goods are expressed in tonne.

Source: BMU; BMWi. 


\subsection{The management of natural resources}

27. With respect to the use of natural resources, both renewable and non-renewable, the debate in Germany has often focused on the use of total resources, one measure of progress towards sustainability being aggregate material usage (defined as tonnes) per unit of GDP (Figure 3). ${ }^{23}$ The justification for recycling and for material audits is often given as the need to preserve world resources rather than reduce pollutants, despite the fact that for many resources the elasticity of supply appears to be high in the long term. Moreover, with respect to renewable resources such as tropical forestry and fishing, over-exploitation may well be a global problem, but domestic policy in a single country can do little to alleviate the problem directly. International agreements are necessary.

28. From the viewpoint of domestic resources, issues arise with respect to forests, bio-diversity and, to a lesser extent, management of water resources. ${ }^{24}$ Forest management has been operated since the nineteenth century on the basis of tree-felling rates close to the rate of regeneration. ${ }^{25}$ To correct pollutant damage to forests will require policies oriented to reducing a wide range of emissions (Box 1), while to secure the external benefits of forests arising from leisure activities and protection of bio-diversity might require restructuring financial supports for forest owners, so as to more closely reflect social preferences (Box 4). With respect to biodiversity, around one half of all vertebrates and about one third of ferns and flowering plants are regarded as under threat while two thirds of biotopes are endangered. ${ }^{26}$ The cause for this situation is the level of pollutants and nutrients as well as more intensive land use in the past on the part of agriculture. A policy framework which takes account of effects across sectors is clearly required with respect to air pollution, as is closer attention to agricultural policy -- to some extent in the domain of EU policy. In this sector the polluter pays principle does not seem to be applied. Rather, current agricultural practices are considered status quo and improvements are interpreted as land conservation and the maintenance of biodiversity which are to be paid for through subsidies. ${ }^{27}$

\subsection{The climate protection programme}

29. The Federal government's climate protection programme ${ }^{28}$ contains over 130 measures for reducing emissions of carbon dioxide and other greenhouse gases, including actions aimed at the sequestration of carbon in forests. In this list of activities all types of policy instruments are represented:

- Most of the programmes contain subsidies, such as those for alternative energy sources, tax exemptions, subsidised loans, public infrastructure investments, and funding of research and development. A correction for the difference between market prices for the use of fossil fuels and their social cost has only been implemented partially, since April 1999 when a new

23. A great deal of effort has been devoted to devising sustainability indicators and over a three-year trial to 1999, 134 indicators are being tested. These indicators cover social and institutional headings pointing to the wide definition of sustainable development which has been adopted in German political dialogue.

24. For the case of water charges and water management see OECD 1999c.

25. Germany's forest area is 46 per cent privately owned and of the remainder 20 per cent is owned by local communities and 30 per cent by the Länder. State forests are centrally managed by each federal state which also exert some influence on local forest administration.

26. BMU (1998d).

27. BMU (1998d).

28. Bundesregierung, IWG (1998). 
energy tax has been applied. The absence of a tax which fully reflects the environmental externalities has led to the need to subsidise or otherwise protect alternative energy sources. The government considers an EU-wide carbon dioxide/energy tax to be necessary. Trafficrelated carbon dioxide emissions are expected to fall due to increased gasoline taxes and measures which increase the attractiveness of local public transport systems.

- A considerable number of emission related laws and ordinances are in force in Germany and these have been tightened. A significant contribution to carbon dioxide-reduction is expected from the Amendment to the Thermal Insulation Ordinance (Wärmeschutzverordnung, WSchV) with a reduction of 7 million tonnes of carbon dioxide in $2005,{ }^{29}$ the Amendment of the Heating Installation Ordinance ( a reduction of 9.7 million tonnes of carbon dioxide in 2005), and the amendment of the Ordinance on Small Firing Installations ( a reduction of 1.4 million tonnes of carbon dioxide in $2005^{30}$ ).

- Two important voluntary agreements are currently in force: the German Motor Industry Association (VDA) promised in 1995 to reduce the specific fuel consumption of cars manufactured and sold in Germany by 25 per cent by the year 2005, relative to the year 1990; industry, represented by the BDI, promised in 1996 to reduce carbon dioxide emissions in 2005 by 20 per cent compared with 1990 levels. The reduction targets are, however, often specified in terms of specific ratios such as carbon dioxide per unit of output rather than as absolute emission levels. In return, the federal government has refrained from introducing additional regulatory instruments covering fuel efficiency for reducing carbon dioxide emissions. Moreover, industry is only subject to 20 per cent of the standard rate under the new energy tax. The commitment by industry is accompanied by a list of reduction targets and a system for verification. The 20 per cent overall reduction is composed of specific sectoral targets agreed upon by different associations organised in the BDI.

- The climate policy initiatives of the German Government include substantial financial resources directed towards information and education about climate change as well as the training of experts. ${ }^{31}$ The awareness of the German public about climate change and climate policy seems to be quite high compared with other European countries or the rest of the world.

- Research on climate change, especially in the natural sciences, has long been supported. Recent efforts go towards interdisciplinary approaches of climate impact research as well as climate policy.

- The development of non-fossil energy sources and energy-saving technologies is also supported by $R \& D$ spending. The historically heavy bias of funding towards nuclear energy research has often been criticised. The IEA's Review of Energy Policies went further, noting that "energy R\&D funding has thus become an instrument for political forces to show that they care about the environment" which involves support for pet projects rather than for promising technologies. ${ }^{32}$

29. All these numbers are taken from Stein and Strobel (1997), Tables 84-87.

30. Bundesregierung, IWG (1998).

31. Bundesregierung, IWG (1998).

32. IEA (1997), p. 146. 
- On the other hand, the government is committed to phasing out nuclear power which is responsible for some 30 per cent of electricity production at present. What such a phase out will imply for green house gas emissions is unclear depending on the pace of closure and the alternatives which might be available to replace the capacity. ${ }^{33}$ However, it is evident that the phase-out will make the government's environmental objectives even more difficult to achieve and strengthens the need for economically efficient policies.

\section{Box 4. Taking into account the external benefits of forests}

Forests not only produce wood for commercial use but also supply a large number of non-market services, such as protection of biodiversity and recreation. The question therefore arises as to how important such externalities might be and how best they can be incorporated into the decisions of forest owners.

In a densely populated country like Germany, forests are used intensively for recreational purposes. Several studies have attempted to estimate the willingness-to-pay for such services. Results of contingent valuation and travel cost studies vary around DM 100 per visitor per year. These yearly numbers are extrapolated from responses from visitors with different lengths of stay in forest areas. ${ }^{1}$ Since the frequency of visits is higher in urban, densely populated areas, the social value of forests in such areas would be correspondingly higher.

Fewer studies have estimated the willingness-to-pay for biodiversity, protection from noise and air pollution and water quality. Those which have been done do not estimate the contribution of forest areas separately but include other natural areas as well. A nation-wide survey on biodiversity preservation found a monthly willingness-to-pay of DM 20 to DM $33^{2}$. A survey of all ecological functions resulted in monthly values of DM 45 to DM 67, of which recreation was only DM 2.50 to DM 5 whereas species preservation contributed DM $16{ }^{3}$ Since separate willingness-to-pay estimates are usually sub-additive, these estimates are at least not contradictory.

The contingent valuation studies show a comparatively large non-market value of recreational and ecological services provided by forests. A willingness-to-pay of more than DM 100 DM -- possibly around DM 200 -- per person per year and a population of just over 80 million leads to an overall willingness-to-pay of DM 8 to 16 billion. This should be compared with timber sales of the German forest sector in 1996 of DM 3.2 billion.

Considering the large non-market value of forest services relative to sales of lumber, the question arises as to whether the forest area in Germany is optimal and whether the owners of forests should be given incentives to take into account the ecological and recreational functions of forests. The results of the contingent valuation studies cannot be taken as a guide to defining the optimal forest area, but the type of forest to be aimed for seems to be clear: mature stands with natural habitat. The maximisation of profit from timber production is unlikely to meet the broader objective of maximising the social value added of forests if only price incentives from wood prices are used.

Private as well as publicly-owned enterprises managing forests already receive subsidies, e.g. for the repercussions following the 1999 storms, for the costs of preventing further damage to forests from air pollution, or simply direct income transfers. Most of these programmes are not explicitly related to the non-market services of forests. A redirection of these subsidies according to the services provided by forest owners as measured through a system of eco-points -- an indicator for the achievement of a socially desirable forest quality -- has been proposed ${ }^{4}$. Such a system could replace some of the direct regulations concerning ecological objectives in forest management. The social efficiency of forest management may be better achieved with such price incentives for the provision of ecological and recreational services.

1. For a review of the results see Elsasser (1996).

2. Hampicke (1991).

3. Holm-Müller et al. (1991).

4. Linckh (1997).

33. A back-of-the envelope calculation suggests the magnitudes which could be involved. With electricity production projected to account for 36 per cent of $\mathrm{CO}_{2}$ emissions in 2005, and assuming all 30 per cent of nuclear capacity would be replaced at average levels of $\mathrm{CO}_{2}$ emissions, the projected decline of $\mathrm{CO}_{2}$ in comparison with 1990 would all but disappear. 


\subsubsection{Moving on from the period of low abatement costs}

30. After a period when improved environmental performance was probably relatively costless to achieve, further improvements are likely to be costly. Figure 4 indicates that the marginal cost of reducing carbon dioxide emission by up to 10 per cent could have been quite low, and similar conclusions can be drawn from the voluntary agreement of German industry, where the reductions achieved to date have been realised quickly in the first years and apparently relatively easily. Three-quarters of the proposed 20 per cent specific reductions (i.e. emissions per unit of output) had been already achieved by 1996. However, in 1997 carbon dioxide emissions increased to 170.3 million tonnes in the concerned industries from 162.3 million tonnes in 1996 (Table 8). The RWI institute, which monitors the voluntary agreement, attributes this relapse to the problem of moving from low cost ("no-regret") to more costly reduction strategies $^{34}$ and if this is so, it seems unlikely that the speed of reduction can be maintained. Similarly, the patterns for other emissions indicate that further improvements are likely to be more difficult to achieve.

Figure 4. Marginal abatement cost of $\mathrm{CO}_{2}$ reduction in the old Länder

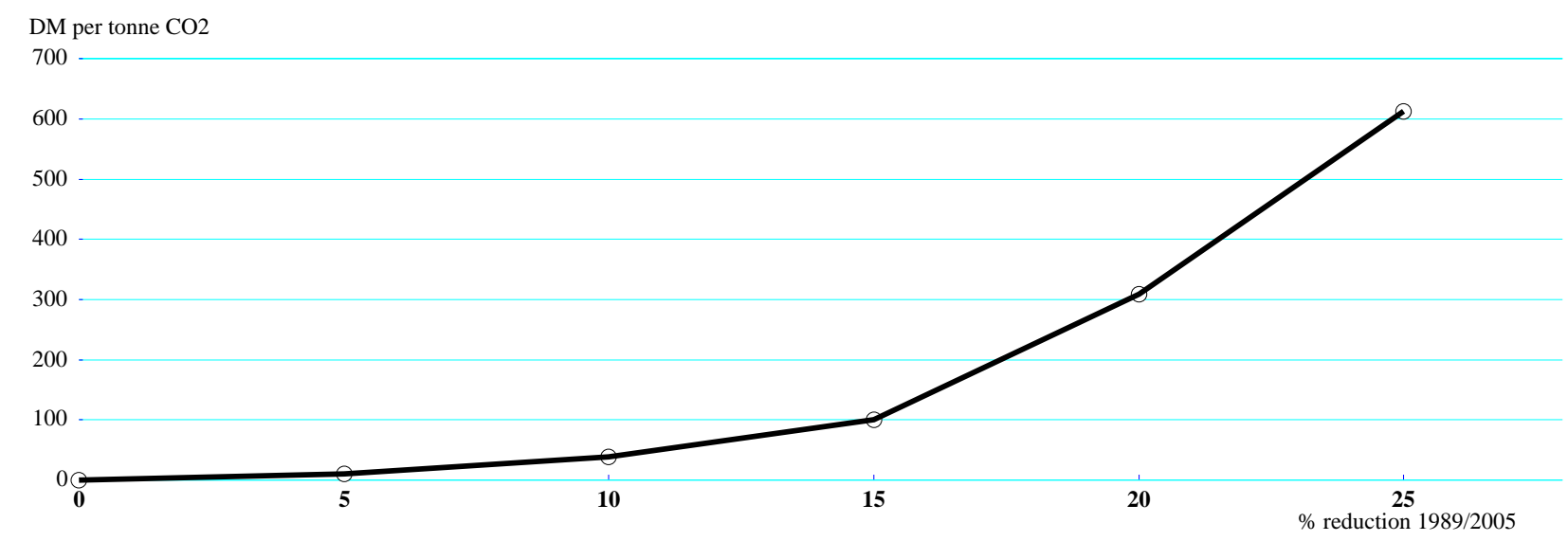

Source: IKARUS model results from Stein/Stobel (1997), Table 139.

34. Buttermann and Hillebrand (1998). 
Table 8. Carbon dioxide reduction achieved by industries signing the voluntary agreement

\begin{tabular}{|c|c|c|c|c|c|c|}
\hline \multirow{2}{*}{ Association } & Base year & 1996 & 1997 & \multicolumn{2}{|c|}{ Reduction } & Target \\
\hline & \multicolumn{4}{|c|}{ Million tonnes of $\mathrm{CO}_{2}$} & \multicolumn{2}{|c|}{ Per cent } \\
\hline Potash industry & 4.8 & 1.1 & 1.1 & 3.7 & 77.7 & 102.5 \\
\hline Cement industry ${ }^{1}$ & 13.0 & 10.2 & 10.0 & 3.0 & 23.0 & 75.3 \\
\hline Lime industry ${ }^{1,2}$ & 2.7 & 2.4 & 2.5 & 0.3 & 9.2 & 78.6 \\
\hline Ceramic tiles and slabs & 0.7 & 0.5 & 0.4 & 0.2 & 35.2 & 87.0 \\
\hline Brick industry & 2.4 & 2.3 & 2.2 & 0.2 & 6.6 & 68.4 \\
\hline Refractory industry ${ }^{1,2}$ & 0.4 & 0.3 & 0.3 & 0.1 & 28.2 & 112.4 \\
\hline Iron and steel Industry & 69.9 & 57.9 & 63.4 & 6.5 & 9.3 & 67.2 \\
\hline Non-ferrous metals industry & 14.6 & 12.7 & 13.4 & 1.2 & 8.4 & 79.2 \\
\hline Chemicals industry & 65.5 & 49.2 & 51.1 & 14.4 & 22.1 & \\
\hline $\begin{array}{l}\text { Wood pulp, paper and cardboard } \\
\text { industry }\end{array}$ & 14.4 & 13.2 & 13.5 & 0.9 & 6.2 & 117.2 \\
\hline Glass industry ${ }^{1}$ & 6.4 & 6.0 & 6.2 & 0.2 & 2.5 & 70.6 \\
\hline Textile industry & 5.8 & 3.9 & 3.9 & 1.9 & 33.4 & 163.2 \\
\hline Sugar industry & 4.5 & 2.6 & 2.3 & 2.2 & 48.0 & 70.0 \\
\hline Total & 205.1 & 162.3 & 170.3 & 34.8 & 17.0 & 85.0 \\
\hline Public electricity supply & 289.0 & 264.0 & 261.0 & 28.0 & 9.7 & 80.8 \\
\hline
\end{tabular}

1. Base year 1987.

2. West Germany.

3. Targets are differentiated between sectors.

Source : Buttermann and Hillebrand (1998).

31. The policies implemented so far concentrate on direct regulations, subsidies, and voluntary agreements, so that relative price incentives for an economic use of fossil fuels have been largely nonexistent. This may well have had already negative implications for efficiency. Table 9 shows the projected sectoral emission reductions from the policies implemented up to 1996. A reduction strategy which better exploited the available technological possibilities would require a somewhat different sectoral composition (column 4). Additional reductions would be needed in private transport, household energy use and energy production. For these reductions to be realised would, however, require changes in relative prices through for instance taxation to take account of the negative externalities arising from the emissions of greenhouse gases and other substances. When even more ambitious environmental targets are considered, the efficiency losses from inappropriate instruments would usually increase more than proportionately. 
ECO/WKP(2001)2

Table 9. Optimal composition of carbon dioxide emissions from energy use, old Länder

\begin{tabular}{|c|c|c|c|c|}
\hline & Actual 1989 & Expected $^{1} 2005$ & \multirow{2}{*}{$\begin{array}{c}\text { Percentage } \\
\text { change } \\
1989 / 2005\end{array}$} & \multirow{2}{*}{$\begin{array}{l}\text { Optimal } 8 \text { per cent } \\
\text { reduction }\end{array}$} \\
\hline & \multicolumn{2}{|c|}{ Million tonnes of $\mathrm{CO}_{2}$} & & \\
\hline Energy production & 227 & 209 & -8 & -13 \\
\hline Industry & 160 & 131 & -18 & -19 \\
\hline Traffic & 134 & 159 & +19 & +12 \\
\hline Households & 115 & 119 & +3 & 0 \\
\hline Small enterprises & 54 & 46 & -15 & -19 \\
\hline Total & 690 & 664 & -4 & -8 \\
\hline
\end{tabular}

1. Expected emissions given climate policies in force in 1996; according to Stein and Strobel (1997).

2. Percentage change in emissions relative to 1989 according to IKARUS-Model simulations. To the baseline cut from existing policies of -4 per cent have been added results from the IKARUS-Model optimisation for lowest-cost cuts of up to 10 per cent.

Source: Calculations by the OECD from Stein and Strobel (1997), Tables 113 and 138.

32. Such price incentives as already exist may be impeded by existing regulatory and legal barriers. Thus, investment in energy-saving insulation of apartments is often not undertaken because owners are not permitted to recoup their costs via higher rents and tenants cannot risk having to write-off their own investment if they move. ${ }^{35}$ For similar reasons, the Bundesbahn has had little incentive to keep costs down through greater energy efficiency, while electricity producers have not been under competitive pressure to raise fuel efficiency until the recent liberalisation. Incentives for individuals and companies to invest in energy saving requires that there be a rate of return to the investor, as well as to society at large.

\subsubsection{Ecological tax reform}

33. One of the new government's major priorities is an ecological tax reform, which has widened the scope for economic instruments. However, implementing the reform has proved difficult for institutional and political reasons. The reform, which came into force in April 1999, raised the gasoline and diesel tax slightly by 6 pfennigs per litre. Light oil and gas taxes were raised considerably and a taxation of electricity was introduced. Nuclear fuels and coal are not subject to a tax and for the latter, domestic production remains subsidised. Because of public concerns about competitiveness and employment, industry and agriculture are subject to only 20 per cent of the standard tax rate (Box 5). In addition, the net tax burden on companies has been capped: companies are eligible for a refund if the cost of the new energy taxes exceeds the notional savings from reduced social security contributions (the employers' contribution rate has been reduced by 0.40 percentage points) by more than 20 per cent. Originally it was intended to exempt the energy intensive sector but this proved impractical and might have contravened EU laws on state aid. Revenues from the tax have been used to reduce social security charges, on the grounds that this will produce the 'double dividend' described above, in the form of lower unemployment and improved environmental performance. The tax reduction for industry and the main focus on end-users as in the taxes on electricity has distributional effects, shifting the tax burden from companies to consumers and towards low income groups. ${ }^{36}$

\footnotetext{
35. Hentrich (1999).

36. Klepper and Scholz (1998).
} 
34. The tax rates on energy are probably inefficient, since they are not based on emissions of carbon dioxide from each energy source ${ }^{37}$. Tax rates in terms of carbon dioxide vary considerably (Table 10). ${ }^{38}$ Gas and oil used in the generation of electricity are not subject to the new tax, although for most plants they remain subject to pre-existing taxes; only electricity itself is subject to the tax. The most carbon dioxideintensive fuel, coal, is not taxed at all. Gasoline taxes are about ten times as high as the taxes on oil and gas, and indirectly on the fossil fuels used in electricity production. Moreover, gasoline appears to be taxed heavily in comparison with diesel which has been kept relatively inexpensive for transport and competitiveness considerations. ${ }^{39}$ While diesel taxes are low, the fixed costs of operating either trucks or diesel cars are high. Local employment considerations have clearly been important in the decision not to tax coal, although another factor was the need not to confer a relative advantage to nuclear power, which would have been contrary to the key objective of phasing out nuclear power generation. ${ }^{40} \mathrm{~A}$ coal tax would also have favoured imported over domestic energy production, particularly of nuclear power: under EU regulations, border taxation of energy imports according to the fuel used in generation is not permitted and would in any case be impractical.

35. As part of its overall budget strategy for 2000 and beyond, the government announced in June that the specific tax rates on petrol and diesel would be raised between 2000 and 2003 by 6 pfennigs a litre each year, while the tax on electricity would be raised each year by 0.5 pfennigs per Kwh. Apart from DM 200 million (the sum will rise in line with the revenues accruing from the electricity tax), which would be used to promote renewable energy sources, revenues will be used to lower the pension contribution rate from 19.5 per cent at present to 18.5 per cent in 2003. The reimbursement scheme for enterprises is to be maintained for the present although it may become increasingly untenable as ways are implemented to circumvent the provision. To guard against such a development as well as to preserve competitiveness, the Ministry of Finance has proposed that the energy tax should be levied on end use only. Proposals to introduce energy audits, which might offset a tax liability for firms, are still under discussion. By and large, it would appear that while the overall level of energy taxation will move in the right direction, the inefficient structure in terms of different implied rates of $\mathrm{CO}_{2}$ taxation remains essentially untouched. Moreover, from the environmental perspective moving to an end-use tax would be a step in the wrong direction since the incentives for an optimal combination of energy inputs would be reduced.

37. It is not possible to be categorical at this stage since externalities associated with other emissions need also to be considered.

38. The tax rates also vary widely if they are calculated not in terms of carbon dioxide but in terms of energy units (i.e. joules).

39. It is not possible to be categorical at this stage since externalities associated with other emissions need also to be considered.

40. One option would have been to impose a tax on fuel rods for nuclear power plants along the lines of schemes already in force in the Netherlands, Sweden and Japan. But the externality argument for this is weak and it would not have resolved the issue of imports of nuclear power. 
ECO/WKP(2001)2

\section{Box 5. Competitiveness considerations in the environmental tax debate}

Competitiveness issues have always been a stumbling block to the implementation of either energy taxes or a pure carbon dioxide tax. Indeed, in countries applying a carbon dioxide tax (e.g. Sweden, Denmark, Norway) energy-intensive industries have always been either tax-exempt or subject to special rates. The arguments traditionally used against the unilateral implementation of a carbon dioxide/energy tax applied to all sectors may appear even stronger in the case of Germany. Energy-intensive industries represent a significant proportion of manufacturing output and industry is strongly export oriented, with markets being characterised by strong price competition. In addition, compared with France, Germany's main competitor on the electricity market, the energy supply is much more carbon-intensive. A high tax on coal-produced electricity would substantially reduce the competitiveness of Germany's electricity production.

Given competitiveness concerns, the government coalition agreement stresses the need for harmonisation of energy taxes at the European level, favouring the introduction of energy taxes at a sufficiently high level to steer behaviour. However, it is unlikely that such a harmonisation will take place quickly. Three proposals have been made for an EU-wide energy taxation system, without agreement. The first two envisaged broad-based additional minimum tax rates on all fuels (except renewables) with a carbon dioxide component and an energy component. It was to be phased in progressively up to a level of US $\$ 10$ per barrel-equivalent. Exemptions were proposed for energy-intensive industries. The proposals met strong opposition from most of the member countries. A new proposal by the Commission in 1997 included a minimum rate taking into account all existing energy taxes, instead of minimum additional tax rates, and the taxation of electricity as a final product. Member states could choose the way the tax would be calculated and energy-intensive industries could be exempted. ${ }^{1}$ This proposal was not accepted by the member countries at the 1999 Cologne summit. Tax measures require unanimity to be accepted.

Competitiveness arguments should be treated with caution. First, the carbon dioxide tax revenues could be used to reduce other distorting taxes (such as labour or corporation taxes), which would favour the competitiveness of less energy-intensive industries. ${ }^{2}$ Second, the effects of a carbon dioxide tax on the competitiveness of energy-intensive sectors are small in comparison with other factors, such as the exchange rate, the wage rate and the overall regulatory burden. In general, the approach to competitiveness is too narrow. What matters in the end is the dynamic comparative advantage -- which in the long run may not be in energy intensive sectors -- and the capability and flexibility of the economy to adjust to changes in relative prices.

In addition, the evidence for significant leakage effects (i.e. the displacement of emissions from countries applying environmental regulation to countries with no or less stringent regulation) is quite weak. It is true that the uncoordinated introduction of a carbon dioxide tax could lead to an undesirable switching of productive capacity, which would be costly to reverse, if other countries were to introduce a carbon dioxide tax later on. However, a gradual phasing-in of the tax (including, for instance, a temporary compensation scheme not related to emissions) could largely avoid such unnecessary costs by giving economic actors due time to adjust and provide sufficient time for the various national authorities to co-ordinate their climate change strategy.

As an alternative to an EU-wide energy taxation, it would be in Germany's interest to support the creation of an international market for greenhouse gas emission permits. It would reduce the overall costs of meeting the Kyoto target by allowing the emission reductions to take place where abatement costs are lowest. To the extent that emission quotas can be partly "grandfathered" for a while (i.e. allocated in proportion to past emissions) a trading system would reduce the cost for the industries compared with a pure carbon dioxide tax, therefore making it more acceptable, while at the same time providing the necessary abatement incentives at the margin. The same could be achieved with an EU-wide carbon dioxide tax combined with a compensation scheme or tax credit which does not modify the incentives to reduce emissions.

1. Bill (1999).

2. Barker (1999).

3. Adams (1997). 
Table 10. Effective taxation of energy sources

\begin{tabular}{|c|c|c|c|c|c|c|c|}
\hline \multirow{4}{*}{ Product } & \multicolumn{2}{|c|}{ Tax burden ${ }^{1}$} & \multirow[b]{2}{*}{$\begin{array}{l}\text { Energy } \\
\text { intensity }\end{array}$} & \multirow[b]{2}{*}{$\begin{array}{l}\text { Emission } \\
\text { factor }^{2}\end{array}$} & \multicolumn{3}{|c|}{ Tax burden ${ }^{1}$} \\
\hline & 1998 & $\begin{array}{c}\text { Increase } \\
\text { since } \\
1 \text { April } 1999\end{array}$ & & & 1998 & $\begin{array}{l}\text { Increase } \\
\text { since } \\
1 \text { April } 1999\end{array}$ & $\begin{array}{l}\text { Total since } \\
1 \text { April } 1999\end{array}$ \\
\hline & DM/litre & DM/litre & M.Joules/litre & $\mathrm{Kg} \mathrm{CO}_{2} / \mathrm{MJ}$ & & $\mathrm{DM} /$ tonne $\mathrm{CO}_{2}$ & \\
\hline & (1) & (2) & (3) & (4) & $\begin{array}{l}(5)=[(1) /(3) / \\
(4) \times 1000)\end{array}$ & $\begin{array}{l}(6)=[(2) /(3) / \\
(4) \times 1000)\end{array}$ & $(5)+(6)$ \\
\hline \multirow[t]{3}{*}{$\begin{array}{l}\text { Petrol }^{3} \\
\text { Diesel } \\
\text { Fuel oil }\end{array}$} & $\begin{array}{l}0.98 \\
0.62 \\
0.08\end{array}$ & $\begin{array}{l}0.06 \\
0.06 \\
0.04 \\
(0.008)\end{array}$ & $\begin{array}{l}34.20 \\
38.60 \\
40.80\end{array}$ & $\begin{array}{l}0.072 \\
0.074 \\
0.074\end{array}$ & $\begin{array}{r}397.99 \\
217.06 \\
26.50\end{array}$ & $\begin{array}{l}24.37 \\
21.01 \\
13.25\end{array}$ & $\begin{array}{r}422.36 \\
238.07 \\
39.74\end{array}$ \\
\hline & $\mathrm{DM} / \mathrm{kWh}$ & $\mathrm{DM} / \mathrm{kWh}$ & & $\mathrm{Kg} \mathrm{CO}_{2} / \mathrm{kWh}$ & & $\mathrm{DM} /$ tonne $\mathrm{CO}_{2}$ & \\
\hline & (1) & (2) & (3) & (4) & $\begin{array}{c}(5)=[(1) / \\
(4) \times 1000)\end{array}$ & $\begin{array}{c}(6)=[(2) / \\
(4) \times 1000)\end{array}$ & $(5)+(6)$ \\
\hline Natural gas & 0.0036 & $\begin{array}{l}0.0032 \\
(0.000640)\end{array}$ & .. & 0.202 & 17.86 & 15.87 & 33.73 \\
\hline Electricity & .. & $\begin{array}{l}0.02 \\
(0.0040)\end{array}$ & .. & $0.560^{4}$ & & 35.71 & 35.71 \\
\hline
\end{tabular}

Note: In brackets, special price for industry and agriculture.

1. Without VAT.

2. Source: Umweltbundesamt.

3. Tax rates are differentiated between leaded and unleaded.

4. For electricity a $\mathrm{CO}_{2}$ emission of approximately $0.560 \mathrm{~kg}$ per produced kilowatt hour results from the underlying energy mix (in the year as well as 1994) and the estimated efficiency factor of power plants. $\mathrm{CO}_{2}$ neutrality is assumed for nuclear power, water power, wind power and other regenerative substances.

Source : Council of Economic Advisors.

\subsection{Air pollution}

36. Air pollution control has been quite effective in reducing emissions from stationary sources and in accelerating the introduction of best available technologies. ${ }^{41}$ Detailed direct regulations with tight guidelines for granting permission to run a stationary source of air-borne emissions have led to a lower level of pollution. By prescribing maximum permissible concentrations of emissions from facilities falling under the regulations, the end-of-pipe technology that can be used is effectively determined. Traffic related regulations also require specific technologies such as catalytic converters. These are, however, backed by tax subsidies. Improvements from these levels of emissions are difficult to imagine given the current state of technologies.

37. Although abatement costs vary significantly across different types of mobile emission sources, and are likely also to vary for stationary facilities in the future as emissions are further reduced, the scope for economic instruments to improve efficiency is rather circumscribed. Emissions need to be measurable

41. Emissions of pollutants into the air are predominantly controlled through the Federal Emission Control Act (Bundesimmissionsschutzgesetz BImSchV) of 1974, the Ordinance on Large Combustion Facilities (Großfeuerungsanlagenverordnung) of 1983, the Ordinance on Small Combustion Facilities (Kleinfeuerungsanlagenverordnung), and the Technical Instructions on Air Pollution (TA Luft). These regulations control power stations, industrial plants, livestock facilities, cars, and household appliances including heating systems. They are tightened according to improvements of the best available technologies. 
close to the source if taxes, charges or pollution permits are to be introduced. This is possible for many gases in stationary and large facilities, but expensive in small facilities and often impossible in mobile emission sources such as cars and trucks. A study of nitrogen oxides $\left(\mathrm{NO}_{\mathrm{x}}\right)$ emission controls through tradeable permits found that only stationary sources, which are relatively homogenous, could be controlled with such an instrument. ${ }^{42}$ Nevertheless international experience does show that gains can be expected from closely-focused emission taxes even in homogenous sectors, particularly with respect to nitrogen oxides emissions (Box 6). For mobile sources a mixture of instruments, including economic ones based on taxing inputs rather than emissions per se, may prove necessary although the underlying principle that policy should seek to equalise marginal abatement costs by all sources remains valid.

\section{Box 6. $\mathrm{NO}_{\mathrm{x}}$ emissions charge in Sweden: positive experience}

In contrast to carbon dioxide, nitrogen oxides emissions $\left(\mathrm{NO}_{\mathrm{x}}\right)$ are strongly influenced by the combustion conditions so that any environmental tax has to take the form of a direct emissions tax rather than as an energy excise. However, the cost of emissions measurement is high. In order to avoid these problems when Sweden introduced a nitrogen oxides charge in 1992, it was confined to a small group of large industrial plants and power stations where monitoring costs were likely to be low relative to potential abatement cost saving. ${ }^{1}$ The tax is based on measured emissions or on presumptive emissions with firms opting for one system or the other. To avoid distorting the pattern of competition between large sources subject to the charge and smaller competitors (and to avoid any incentive to substitute small boilers) almost all the revenues from the tax are returned to the participating sources in proportion to their final energy output. Thus, sources with high emissions relative to their energy output are net payers.

After 20 months in operation, a commission examined the initial experience. Emissions had been reduced by 55 per cent and the marginal abatement cost between sources had been high ranging from SKr 4000 to SKr 52000 with an average of SKr 10000 per ton. It was also found that changes in operating procedures for a given plant could have a significant impact on the level of emissions without any change in the technologies employed. In order to encourage emissions conscious behaviour by employees (and hence savings in tax payments) some plants introduced wage bonuses relating to emissions reductions which the plant had achieved.

1. For details see (S. Smith, "Environmental and public finance aspects of the taxation of energy", Oxford Review of Economic Policy, 14, No. 4 , 1998.

38. An important condition for the effective use of economic instruments is that emissions should not be concentrated in local areas termed "hot spots". Otherwise, economic instruments need to take account of the local emission situation in terms of timing and locality. In the extreme, where instruments have to be shaped to local circumstances, they are little different from direct regulation of emission sources. ${ }^{43} \mathrm{~A}$ further inhibiting factor is that a facility such as a fossil fuel combustion plant usually emits a large number of different hazardous substances. Tax rates would need to be set for each of these and it is not clear how this should be done. For example, because many of these emitted substances are jointly produced, this would require tax rates which are conditional on the complementarity of the processes creating emissions. Since this is unlikely to be achievable in many circumstances, the regulating authorities may need to resort again to the direct regulation of plants or processes. Large combustion facilities may therefore be easier and more efficient to control through the existing system than through a complex set of tax rates. What is needed is a careful assessment of the costs and benefits of differing policies for abatement control. In this respect, international experience shows that in those cases where only a single or few substances are emitted, or where the substances are emitted in fixed proportions, economic instruments could play a role.

42. Heister et al. 1990.

43. Ibid. The NOx-study also found that the permissible air-sheds need to be quite small and will result in very thin markets for emissions permits or in locally differing emission taxes. The computational and administrative requirements for localised emission taxes could be substantial. 
In particular, the establishment of a trading programme for sulphur dioxide from electricity generation for the United States as a whole, to address the acidification problem, has allowed cost savings from emission reduction compared with command and control instruments (Box 7). ${ }^{44}$ This system has also proved compatible with control of particularly high local levels of pollution (hot spots).

39. In Germany, existing regulations sometimes treat sources differently, leading to an inefficient level of emissions. One example is the incineration of waste. The new Waste Law allows competition between waste incinerators and industrial incinerators for burning waste. The required standards for emission concentrations are identical for both facilities, but the required standard of best available technology is defined differently for the two processes, resulting in different costs of abatement equipment. ${ }^{45}$ The apparent over-capacity of waste incinerators may, among other things, be attributable to the cost burden imposed on the disadvantaged sector by the regulation. Another example concerns the different treatment of stationary and mobile sources. Emissions from non-stationary sources -- mostly coming from traffic -- have not been reduced nearly as much as those from stationary sources in the case of nitrogen oxides. As a result, the share of traffic-related emissions has been increasing, to almost 70 per cent (see sectoral discussion below). It is clear that further emission reduction measures will need to concentrate on such mobile sources, and for this traffic-related policies will be indispensable. A reduction in traffic will probably be needed as well as refinements to fuels and engines which will require a balance of economic and regulatory policies.

40. In sum, with respect to the control of air pollution, Germany has chosen an approach setting allowable emission concentrations, specifying best available technologies, and licensing emitting facilities. This policy has resulted in remarkable reductions in the emission of most hazardous substances from stationary, mainly large, facilities although whether this has been at least cost is not clear. Smaller facilities have been subjected to similar regulations, whereas mobile sources such as traffic-related emissions account for an increasing share of pollutants. Further reductions will need to come from mobile sources, since additional contributions from stationary sources might only be possible with large and increasing abatement costs. In moving forward greater reliance may need to be placed on economic instruments so as to achieve ambitious environmental targets at least cost. Experience in other countries shows that this is a viable complement to regulation.

\subsection{Water pollution}

41. The regulatory system requires every firm or institution which discharges waste water into surface waters to obtain a permit from the local authority. ${ }^{46}$ This is only granted if waste water is treated according to the generally-available technology. In addition, a charge is levied on waste waters, this being practically the only emission which has been directly targeted by an economic instrument in Germany. ${ }^{47}$ However, the charge is applied in a discriminatory way. Charge rates are reduced for emitters who use best available technology and they can also be reduced for local reasons. Having been designed to create incentives for additional reductions in those cases where marginal abatement costs are comparatively low,

44. For a wider review of experience in implementing permit schemes see OECD (1999d).

45. SRU (1998).

46. Water quality in surface waters is regulated by the Federal Water Management Act. The federal government has only authority to establish framework legislation whereas the administration and control is given to the Länder and county authorities. An exception is the waste water charge which is part of the Federal Water Management Act and which is administered on the federal level.

47. The vehicle tax has been reformed so as to be more closely related to the estimated level of emissions. 
recent amendments have been strongly criticised as undermining its original incentive function. ${ }^{48}$ Charge rates differentiated according to the technology used and the emission concentrations distort the incentive of the waste water charge. ${ }^{49}$ And a major inefficiency arises from provisions which permit the charge to be offset against investments in new sewage systems or their repair and with investments in the treatment of a particular substance which are made in a treatment plant. This is believed to lead either to symbolic investments in order to avoid the waste water charge ${ }^{50}$ or to a subsidy on investment which a company is legally bound to make anyway, thus increasing the deadweight loss of the charge.

42. The control of non-point water-pollution emissions has not kept pace with the control of point sources, the former now contributing 60 per cent of the nutrient load, mostly from agricultural sources. So far the nutrient input in agriculture is partially regulated through regulations of agricultural practices, e.g. for the use of natural manure or maximum levels of fertilisers to be used annually. However, price signals such as a nitrogen tax on fertiliser or tradeable permits, are not used, although they might contribute to reaching a more efficient level of fertiliser use. In their absence, and although a great deal has been achieved in reducing water pollution, the instruments in place have not been effective enough to meet the environmental targets in a cost-efficient manner.

43. Germany has a number of waste problems including hazardous and nuclear waste but packaging and other consumer related waste issues have received disproportionate public attention. ${ }^{51}$ During the 1980s there was increasing concern about the future volume of waste which was expected to be generated, most projections indicating that continuing rapid growth would bring increasing pressure on scarce landfill capacity, together with dangers from soil and water contamination. In response, the waste management Law of 1986 specified a hierarchy of priorities: waste avoidance, waste recycling and waste removal, in declining importance. ${ }^{52}$ This policy logic was extended in 1996 with the concept of "product responsibility" by which producers are responsible for their products from "cradle to grave". Most importantly, the law determines that producers and distributors of goods can be obliged by ordinances to take back their products after use and to "reprocess" a predetermined share of the waste (Verwertung). Similarly, the last owners of a product can be held responsible for returning the goods after use. The government can also assign the costs associated with the various stages of waste management to the different parties involved. In implementing the policy, considerable emphasis has been given to establishing voluntary agreements with industry (Box 8). Measured in terms of waste reduction and the proportion of waste that is being recycled, the German waste policy has been quite effective. At present, about one-third of all waste is being recycled, with the recycling quota of industrial waste, which is relatively homogenous, amounting to some 60 per cent (Figure 5). With respect to packaging, which only accounts for about 5 per cent of total waste, recycling ratios ranging from 79 per cent for composite materials to 94 per cent for paper and board have been achieved and per capita consumption of packaging material has declined from $95 \mathrm{~kg}$ in 1991 to $82 \mathrm{~kg}$ in 1995.

48. SRU (1996). The expert council for the environment in its 1996 report stated: "The waste water charge has deteriorated from an incentive charge towards a pure financing instrument and the argument for levying the charge as well as the underlying economic argument are not convincing”.

49. See e.g. Meyer-Renschhausen (1990) or Maas (1987).

50. SRU (1996).

51. Nuclear waste issues are discussed at length in IEA (1998).

52. The waste management law, the Law on Circular Flow Economy and Waste Management (Kreislaufwirtschafts- und Abfallgesetz, $K r W$-/AbfG) came into force in October 1996. 


\section{Box 7. Emission trading in the United States}

The United States has two large-scale "cap-and-trade" schemes currently in operation. Permit trading in a nation-wide $\mathrm{SO}_{x}$ scheme covering emissions by electricity generators began in 1995 and that in a $\mathrm{NO}_{x}$ scheme covering twelve north-eastern states began in May 1999. The $\mathrm{SO}_{\mathrm{x}}$ scheme is operated under federal legislation in an 1990 amendment to the Clean Air Act, whereas the $\mathrm{NO}_{x}$ scheme is operated under a voluntary agreement between the states concerned. Although emission trading had been an option under a number of regulatory programmes from the 1970s onwards, the $\mathrm{SO}_{x}$ scheme is the first to be thought successful; the failure of earlier schemes -- in the sense that no true markets ever developed -- is attributed to the fact they were adjuncts to command and control schemes, with restrictions on trading that rarely made it worthwhile. The $\mathrm{SO}_{\mathrm{x}}$ scheme was the first in which the cap and trade system is relied on almost entirely for emission control.

\section{The $\mathrm{SO}_{\mathrm{x}}$ scheme}

This scheme has a number of notable characteristics: permits are geographically undifferentiated; allocation is almost entirely based on the product of a performance standard and representative utilisation levels, though a small proportion are auctioned each year; in the first few years of the scheme only large emitters were covered, smaller emitters being included from 2000; trading is very flexible -- "banking," in which unused allowances can be carried forward, is allowed, as is forward trading; trading is not restricted to emitters and reporting requirements are not burdensome; non-compliance penalties are severe (a fine of $\$ 2000$ per ton, some ten times current permit prices, and at least three times most earlier estimates of the permit price). The aim is to reduce overall $\mathrm{SO}_{\mathrm{x}}$ emissions from power generation to 50 per cent of their 1980 value in a progressive tightening from 1995 onwards.

Evaluation of the scheme is complicated by the fact that caution over whether trading would be feasible led many emitters to cut their emissions more than necessary, and that expanding rail capacity and deregulation meant that a low-cost option of switching to low-sulphur fuels became much more widely-available. Actual emissions have thus been substantially under the target, with some banking in anticipation of a tighter future market, and permit prices were much lower than initial projections for several years, though they have risen since mid-1998. After a period of about a year during which trading was thin, and it was not clear what "the" market price was, trading grew rapidly and independently of the official auctions, and a going price has been well established since 1996.

The absence of geographical differentiation has not led to emission "hotspots" as some had feared, with some of the largest emission cuts coming in areas with high initial emissions and sources are still required to limit emissions to prevent violation of health-based air quality standards. Reasonable estimates of the savings due to trading suggest that abatement costs were reduced by between a quarter and one third, though these depend on what alternative scheme is considered (Schmalensee et al., 1998).

\section{The NO scheme}

This is similar to the $\mathrm{SO}_{x}$ scheme, with twelve of the states that comprise the Ozone Transport Commission having delegated the running of the scheme to the federal Environmental Protection Agency. The aim is to reduce summertime (May-September) $\mathrm{NO}_{\mathrm{x}}$ emissions to less than half their 1990 level, with the reduction taking place in two steps -- in 1999 and 2003. An interesting difference is that the penalty for non-compliance is specified as confiscation of permits equal to three times the size of the violation; individual states retain the power to fine non-compliers up to $\$ 25000$ per ton in their own state. Another important difference is that emitters remain subject to various technology standards set by the EPA. Although permits were allocated by each state over a period of a year beginning in September 1998, conditional trading began in late 1997; since then 1999 vintage prices rose to around $\$ 3000$ per ton by late 1998, spiked at over \$6 000 in March 1999 before declining to under \$2 000 in July. 


\subsection{Waste disposal}

44. Quotas for re-use, recycling and energy and non-energy recovery have conflicted with underlying market developments and have led to a number of economic and environmental issues:

- Quotas for recycling etc. are second best to a policy for landfilling based on differentiated fees targeted directly at the externalities (volume of and emissions from landfilling). ${ }^{53}$ This would require, however, that fees for waste processing be corrected for the costs of emissions into air and soil. Public waste management facilities are currently not even allowed to charge the full cost of waste collection, recycling and removal due to accounting regulations for public institutions. ${ }^{54}$ They are also not allowed to charge shadow prices for incineration and for landfill. Such a system would improve efficiency in the disposal of waste.

- Waste intended to be reprocessed is often transported over long distances, and the associated pollution would have to be taken into consideration for a comprehensive environmental evaluation of the waste processing strategy. ${ }^{55}$ The restrictiveness of waste-processing quotas for packaging material has been evidenced in increased inventories of waste material. (In response, the range of admissible modes of reprocessing packaging material has been widened in 1998, including now certain types of combustion.)

- Identifying the material to be subjected to quota opens another source of distortion. The packaging ordinance requires that packaging materials be separated from other recyclable waste of the same material in the collection and sorting stages, whereas efficient recycling should treat the same material equally to avoid unnecessary costs. ${ }^{56}$

- Quotas restrain the utilisation of other forms of waste processing which might turn out to be more environmentally friendly and economically efficient. For example, following the marked reduction of polluting gas emissions due to technological progress, incineration and energy recovery facilities could offer a more efficient and environmentally friendly means of recycling.

The German system needs to be developed further by widening the admissible channels of waste processing so as to allow price signals to play a larger role in the waste allocation process.

53. For a practical example applied in the United Kingdom of a landfill tax oriented to these ends see David Pearce, "Cost Benefit Analysis and Environmental Policy", Oxford Review of Economic Policy, Vol. 14, No. 4, 1998, and articles therein.

54. $\quad$ Sachverständigenrat für Umweltfragen, Umweltgutachten 1998, Wiesbaden 1998.

55. Waste designed to be re-processed might be transported without legal restrictions over any distance, while there are legal restrictions on the transportation of waste intended to be dumped.

56. The repercussions of this inefficient arrangement became clear when households also deposited nonpackaging waste of the same material in the waste containers for packaging material. In 1993, nonpackaging material (including non-recyclable "residual waste") accounted for 40 per cent of the waste deposited in the bins of the voluntary Dual System. This contributed to a financial crisis of the scheme in the first half of the 1990s, since the Dual System was obliged to compensate waste processors for the collected non-packaging waste as well. See Benzler, Guido, Marianne Halstrick-Schwenk, Paul Klemmer and Klaus Löbbe, "Wettbewerbskonformität von Rücknahmeverpflichtungen im Abfallbereich", Untersuchungen des Rheinisch-Westfälischen Instituts für Wirtschaftsforschung, No. 17, Essen, 1995. 
Figure 5. Treatment of municipal waste ${ }^{1}$

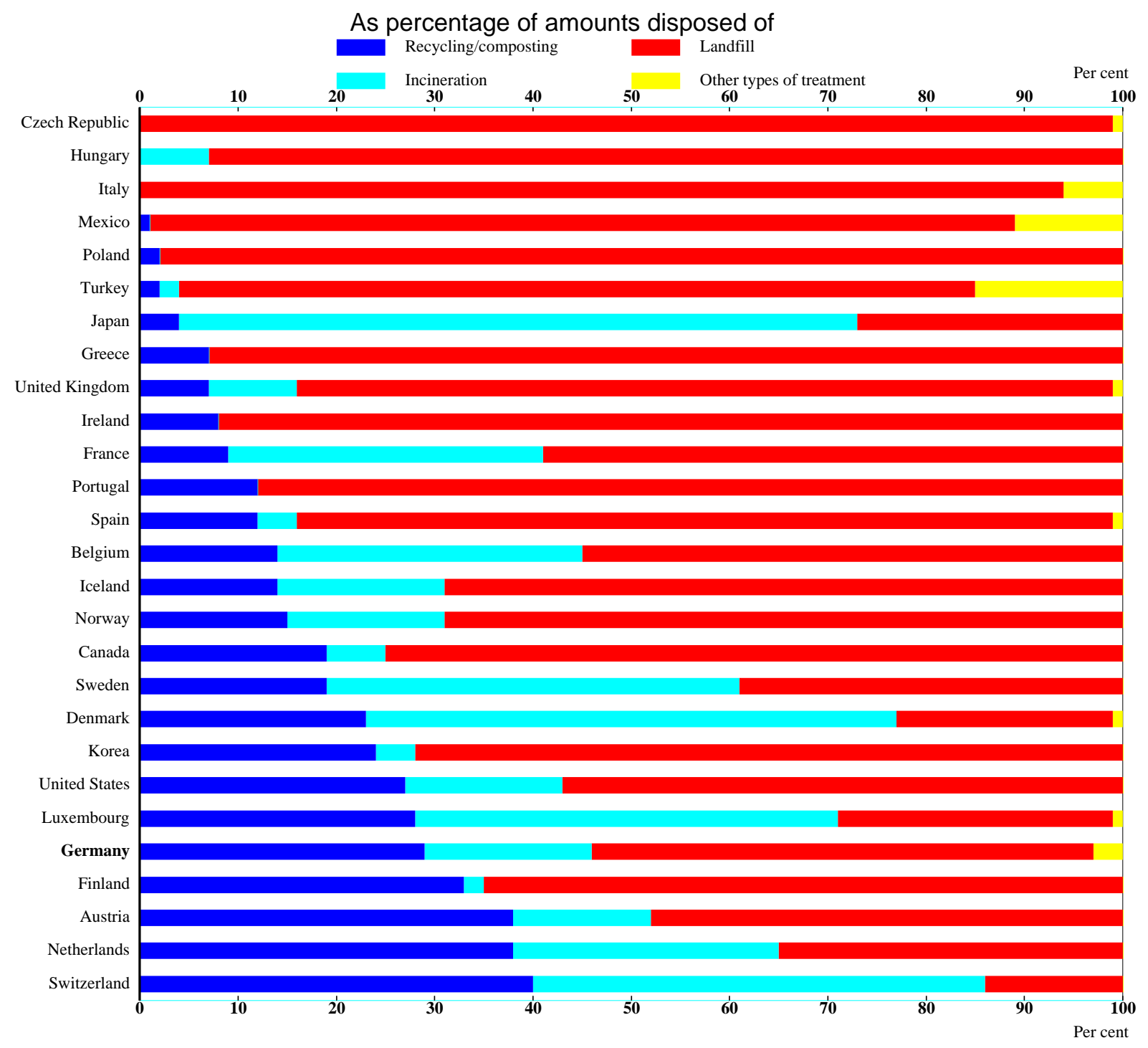

1. Mid-1990s. Municipal waste is waste collected by or on the order of municipalities. It excludes waste from municipal sewage networks and treatment, as well as municipal construction and demolition waste. Recycling data not available for Italy; incineration data not available for Ireland.

Source: OECD, OECD Environmental Indicators. 


\section{Box 8. Voluntary agreements covering waste disposal}

The goals of the Waste Management Act have been implemented through voluntary agreements (Selbstverpflichtungen) which in some cases have been underpinned by ordinances.

- The packaging ordinance, which came into force already in 1991, is the most far-reaching ordinance on waste processing. Producers and distributors of packaging material have been made liable to take back their packaging material. In addition, the ordinance determines what fraction of the waste -- broken down by material -- must be "reprocessed" (verwertet) rather than being dumped. The definition of "reprocessing" has been widened with the most recent amendment of the ordinance and now also includes forms of combustion for the purpose of energy recovery, in addition to pure recycling which was the focal point of the first version. Firms have the choice of meeting their obligations individually or to participate in a collective scheme which organises the relevant aspects of waste management. The majority of firms choose the collective solution. This led to the establishment of a single private waste management company, the "Dual System Germany" (Duales System Deutschland), which commissions collection of waste packaging and grants contracts with firms to guarantee its processing. Producers of packaging material participating in the scheme label their wrappings with a green dot (grüner Punkt) for which they have to pay licence fees that cover the costs of the system. This has been extended by an ordinance in 1998 specifying recycling standards and collection quotas.

- In 1988, the battery industry committed itself to establish a take-back system for batteries and improve the labelling with respect to hazardous substances in the batteries. The scheme has been extended by an ordinance in 1998 which specifies recycling standards and collection quotas.

- The paper industry entered into a voluntarily agreement in 1994 to raise the recycling quota for printed material to 60 per cent by the year 2000. In 1995 as much as 72 per cent of paper was already recycled.

- The construction industry -- apart from the large construction companies which develop their own recycling strategy -- has announced that it will voluntarily reduce the quantity of construction waste. Between 1995 and 2005 , the amount of waste relative to the value of new buildings and constructions is to be reduced by 50 per cent. It is not clear whether this goal will be reached (SRU 1998).

- The Automobile Industry Association -- in a reaction to a planned ordinance on the recycling of used cars -signed a voluntary agreement on a modified take-back guarantee of used cars and car parts and on reducing the share of non-recyclable parts in cars. In response, the government did not further pursue the planned ordinance in the original form. Instead, the voluntary agreement was specified in the new ordinance in 1997. In the selfbinding arrangement, the car producers have bound themselves to accept used cars without charge which are up to twelve years old. An EU proposal for a European wide ordinance was vetoed by several governments, including Germany, on the grounds that it would put their producers at a competitive disadvantage.

- In 1991 the government presented a draft ordinance on the waste management of electrical appliances and electronic components, specifying take back and reprocessing obligations. The ordinance is still being debated, and proposals for voluntary agreements have been made, but no final agreement has been reached.

45. Greater use of market mechanisms presuppose the creation of efficient markets but in the waste area a great deal of progress is necessary. The establishment of a single waste management company, which works on behalf of all packaging-producing firms participating in the Dual System, has been repeatedly criticised for restraining competition between processing firms at different stages of waste disposal. Moreover, the waste disposal industry is highly concentrated, due in great measure to the strong position of local utilities. Without some form of central waste management each firm using packaging would be individually responsible for securing waste collection, sorting and processing, which would clearly be less efficient than a co-operative solution. Nevertheless, the system has revealed deficiencies with respect to competition which point to shortcomings in the regulatory framework. Competition between waste collectors is virtually absent. Contracts for waste collection are granted to just one firm per region, often without the need to re-tender for a period of ten years. While the revised ordinance of 1998 now requires open tendering and shorter contracts, market contestability will remain restricted by the long 
duration of existing contracts. More importantly, the market structure has been adversely influenced by the provision in the Packaging Ordinance requiring that waste collection and processing within the Dual System has to be co-ordinated with the collection and processing systems of the local communities. Not surprisingly, some 25 per cent of waste collectors under contract to the Dual System are communal firms or firms with communal participation.

46. As noted in Box 8, "self-binding arrangements" (Selbstverpflichtungen) by industry have been used extensively, but some have been criticised for achieving only what would have materialised without intervention, as well as for giving industry a disproportionate say in environmental policy. ${ }^{57}$ For example, it has been suggested that the free take-back guarantee for cars up to a maximum age of twelve years does not essentially contribute to the environmental objective of reducing the volume of shredder waste (which is classified as hazardous). ${ }^{58}$ Most cars for scrap are not under twelve years of age, the mean age at disposal being 13.2 years. The pledge to take back cars free is also redundant since such cars still fetch a positive market price. More generally, to the extent voluntary arrangements are costly for participating firms, they may be unstable if free-riding cannot be excluded. ${ }^{59}$ Moreover, there might be a danger that self-binding arrangements allow insiders to the agreement to set standards in their own interest and at the expense of potential competitors.

47. In sum, the move toward "product responsibility" represents an important step towards internalising environmental costs of products at the stage where it matters most: that of product design and manufacture. However, the priority given to recycling per se has led to some adverse economic and environmental outcomes, so that price signals should be allowed a greater role in decisions about the final destination of waste. This distortion has been compounded by the fact that industrial activities in the sector are not based on competitive market conditions.

\section{Selected sectoral issues}

48. Although policies for more environmentally-friendly growth need to be considered broadly in terms of the specific environmental target, widely differing monitoring costs mean that policies might have to be designed on a sector-specific basis. For example, the need to lower nitrogen oxides $\left(\mathrm{NO}_{\mathrm{x}}\right)$ emissions might need different policies for cars and trucks compared with those oriented to large, stationary, installations. On the other hand, sectoral policies often have a number of environmental implications which need to be considered. This section examines policies in four key sectors: electricity, coal production, transport and agriculture.

57. Sachverständigenrat für Umweltfragen, Umweltgutachten 1998, Wiesbaden 1998.

58. In fact shredder waste -- waste left after all other recoverable materials have been removed -- only amounts to 1.5 per cent of the domestic waste volume. It is however classified as hazardous.

59. In the Dual System, some firms did not acquire a "Green Point" licence but benefited from the fact that participating firms contributed to fulfilling the prescribed reprocessing quota collectively. To close this loophole the ordinance was revised in 1998, now requiring firms to prove that they either fulfil their disposal obligations individually or participate in a collective system 


\subsection{Electricity: reconciling efficient supply with environmental objectives}

\subsubsection{Liberalisation and the promotion of alternative sources of energy}

49. The liberalisation of the electricity sector has brought lower prices and this tendency is expected to continue if competition is allowed to develop. ${ }^{60}$ This development has raised two environmental policy questions: $i$ ) are lower electricity prices (and lower oil and raw material prices for that matter) compatible with achieving environmental goals; and ii) what should be the policy with respect to fuel substitution? In particular, should renewable energy sources, which are generally more expensive than gas or oil-fuelled generators, be promoted in the framework of competition in the energy market and, if so, how?

50. Increased competition following liberalisation places generating companies under pressure to select low cost energy sources and to make sure that the conversion of primary energy to electricity is energy efficient. Improved efficiency resulting from competition should be welcomed from an environmental and economic perspective. Ceteris paribus, this development has reduced the long term attractiveness of both nuclear power (an environmental policy goal) and coal to the advantage of gas. For the market to work efficiently, however, will require sound and reliable framework conditions, a point stressed by the IEA in its energy policy review of Germany, and correct price signals. Lower electricity prices could be expected to raise consumption although the effects on carbon dioxide emissions will depend on the energy mix. As noted above, in view of the Kyoto commitments the best solution would be to impose a tax or tradeable permit on carbon dioxide emissions associated with primary energy inputs rather than to tax electricity.

51. Electricity liberalisation includes special provisions for electricity produced from renewable sources (such as wind, solar and bio-mass) to be given access to the grid at above-market prices, the excess being treated as a network cost to be paid by all customers of the network involved. Access is limited to 5 per cent of transmissions. Integrated generation/heating systems, which are regarded as environmentally friendly because of their high rates of energy efficiency, are also given special protection, by allowing third party access to be denied under some circumstances. ${ }^{61}$ With the energy tax reform of April 1999, support has been further increased: taxes on electricity based on renewable energy sources will be refunded in the form of development grants, while the existing taxes on mineral oils and natural gas have been abolished for energy-efficient integrated generators. Support measures which ensure higher prices for renewable energy sources in local markets are unlikely to be effective for long in a liberalised electricity market where companies can move operations out of high cost areas. A quota scheme for energy from renewable sources has been put forward as an alternative but the question would arise as to the price which would be paid for such electricity. Moreover, at some stage preferential access is likely to prove incompatible with the liberalised European electricity market. More generally, protecting alternative sources of electricity generation is a second best policy, the first best being to tax primary energy on the basis of relative emissions. As noted above, this latter course of action would probably require agreement at the EU level.

52. Although appropriate pricing of primary energy inputs would place all sources of electricity generation on a more equal competitive basis (nuclear power raises other issues), thereby reducing the need for special support programmes, special issues do need to be addressed with respect to integrated generation/heating systems. Several factors appear to make such systems at present uncompetitive. ${ }^{62}$ The capital costs are large and heating for residential purposes is only used for part of the year, at which time the energy efficiency is indeed high. For the remainder of the year it is not. Another problem appears to be

60. See, OECD, Economic Survey of Germany (1999), Chapter III.

61. OECD, Economic Survey of Germany (1998).

62. IEA (1998), pp. 71 and 119. 
that since the integrated generators are city based (Stadtwerke) their scale might be too small to be efficient. Indeed, this appears to be the case in cities producing only electricity. The case for an across-the-board protection of combined generators is thus questionable. An undistorted system of environmental taxation would help direct the inevitable restructuring of city generating capacity in the direction of economic efficiency and the attainment of environment targets.

53. As noted above, an important goal of the government is the eventual closure of nuclear power generators, which account for about 30 per cent of Germany's electricity generation. The goal is to achieve this closure gradually and by a voluntary agreement with the companies, both in order to preserve security of supply and to avoid payment of compensation to the owners. This is a political decision which will affect the attainment of environmental targets. Even if nuclear energy is replaced by gas-turbine generators, which can be brought into operation relatively quickly, these are still associated with $\mathrm{CO}_{2}$ and other emissions. Technological advances may, of course, create future energy savings, but it will be important that unrealistic assumptions are not made about the short term capacity of the economy to realise these. A phase-out of nuclear power would thus have to be underpinned by other concrete policy measures.

\subsection{The coal industry: conflicting objectives}

54. The coal industry represents an example of the conflict between narrow definitions of economic interest and wider concepts of both economic welfare and environmental objectives. Not only has hard coal continued to be subsidised -- although at a declining rate -- but one state government recently fought to have a new coal fired station established in its state in order to preserve jobs. Moreover, lignite production (with a high carbon dioxide emission intensity) in the new Länder is being supported until 2003 (with an option to extend to 2005) by guaranteed access to the grid at higher prices for electricity produced from this fuel. At the same time, the stated objectives of Germany's coal policy are reductions in the sales of subsidised coal for electricity production and in the steel industry. Extraction costs are not competitive with other foreign suppliers, amounting to around US\$50/tonne for brown coal and US\$200/tonne for hard coal, ${ }^{63}$ far above world prices which has led in the past to subsidies. These reached a peak between 1987 and 1995 with roughly DM 12 billion per year. ${ }^{64}$ This amounted to a subsidy per worker in coal mining of roughly DM 100000 per year ${ }^{65}$ and a producer subsidy equivalent of over $\$ 100$ per tonne (Figure 6). In 1997 the support programme for the coal industry was changed to direct payments from the Federal government and the state Nordrhein-Westfalen. ${ }^{66}$ Subsidies will be reduced from DM 8.9 billion in 1997 to DM 5.3 billion in 2005, although the rate of decline is not rapid (Figure 7). The new government has decided not to change this plan. The extraction path of hard coal has been largely unaffected by the different policy measures. Since the peak production of about 140 to 150 million tonnes around 1960, output has more or less continuously fallen to 46.5 million tonnes in 1997. However, the IEA's Review of Germany, 1998, noted that the decrease in the United Kingdom and French production had been more rapid. Capacity will be further reduced to 30 million tonnes in the year 2005. About one half of the mines will be closed between 1997 and 2005. ${ }^{67}$ In the same period employment will fall from 85000 to 36000 . In order to manage this process the German coal companies have merged in the "Deutsche Steinkohle AG'.

\footnotetext{
63. Heinloth (1997).

64. Storchmann and Kyro (1997).

65. Neu (1995).

66. See OECD Economic Survey of Germany (1997).

67. Beermann, (1998).
} 
Figure 6. Subsidies to hard coal production

Producer subsidy equivalent (PSE)

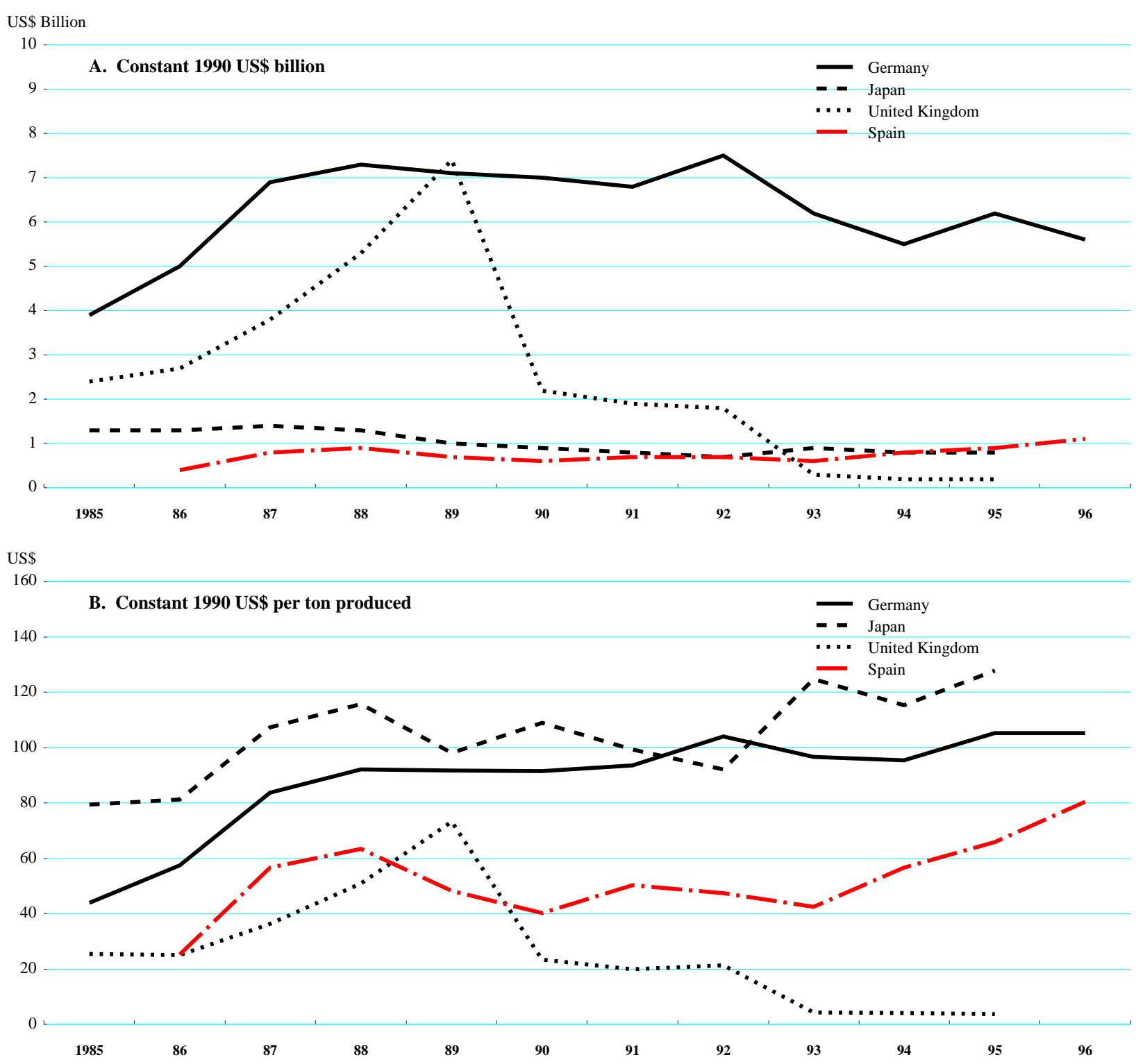

Source: International Energy Agency (IEA). 
Figure 7. The financial aid programme to the coal industry

\author{
Planned payments in billion of Deutchmarks
}

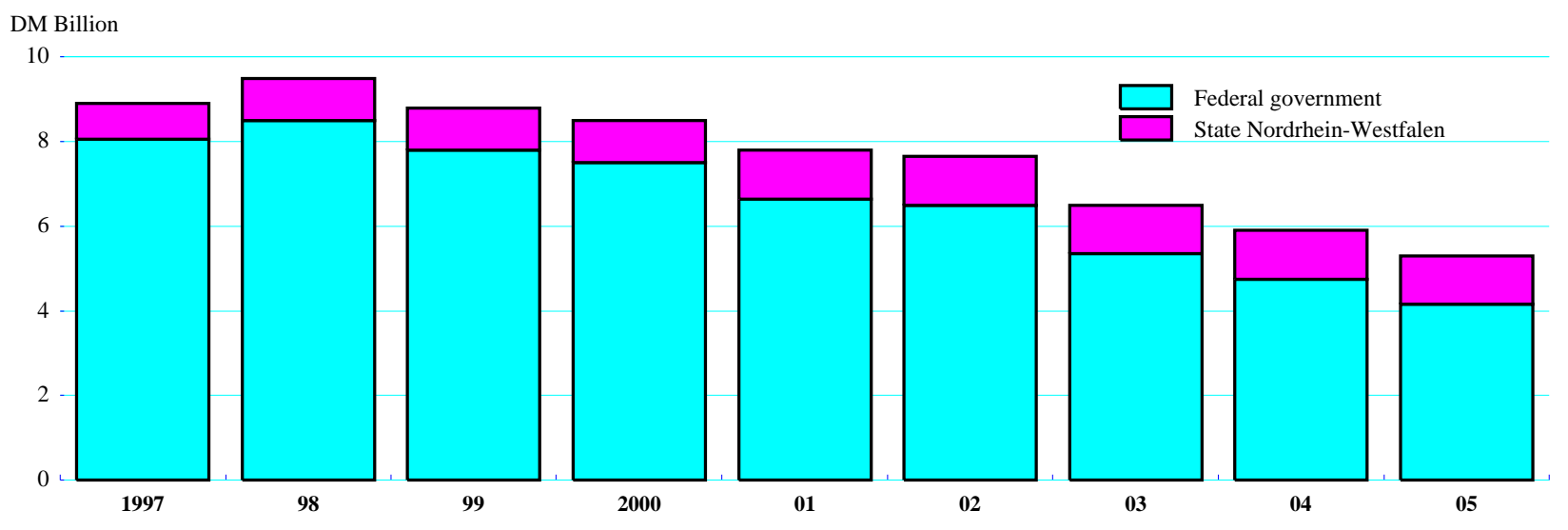

Source: Storchmann/Kyron (1997).

55. Although lignite production is not subsidised and output has been reduced, two Länder have taken measures to maintain production through subsidies for the building of two new generators. In addition, under the contract for privatisation of VEAG (the supra regional utility in the new Länder) the company undertook to modernise lignite fired power plants and the building of new plants. The commitment was to invest DM 20 billion of which DM 3 billion had been invested by 1997. Access to the grid at higher prices is ensured up to 2003 and possibly to 2005 .

56. The policy of subsidising coal extraction and of encouraging the use of coal for electricity generation contradicts the climate policy objectives of the German government since coal has the highest carbon dioxide content of all fossil fuels. This policy has induced a structure of power plants strongly oriented towards coal incinerators making it difficult to switch to fuels with a lower carbon content, since these power plants represent high sunk costs with a service life of several decades. Moreover, even if subsidies were to be cut, low price imported coal would extend the working lives of the plants. In the next decade several plants nevertheless need to be replaced which will place a premium on having a consistent policy framework in place. A continued orientation towards coal would direct long-term investments in a direction contradictory to climate objectives.

\title{
5.3 Traffic and transport
}

57. Traffic contributes importantly to both carbon dioxide and other air pollution emissions and is responsible for a wide range of local environmental problems such as congestion and noise. Although $\mathrm{CO}_{2}$ emissions from the transport sector stabilised in 1996 and 1997, it is too early to say whether this will hold once overall economic activity accelerates since efficiency gains in fuel use have tended to be offset by rising transport volumes. ${ }^{68}$ This is particularly so with respect to road transport where tonnages have

68. “ $\mathrm{CO}_{2}$ Emissionen in Deutschland: Weiterhin vom Zielpfad entfernt”, DIW Wochenbericht, 6/99, February, $(1999 a)$. 
increased by a quarter in the period 1990/1995, as well as in air transport (both domestic and international). A number of studies suggest that externality effects are not fully captured by current transport pricing. ${ }^{69}$ One estimate ${ }^{70}$ puts the uncovered social costs of road transport in Germany at around $2 \frac{1}{2}$ per cent of GDP in the early 1990s, about half of which was due to air pollution and $\mathrm{CO}_{2}$ emissions. The valuation of these latter effects is certainly too low since the shadow price of emissions has risen in line with changed environmental objectives. Even though transport charges have risen in the intervening period, the estimate is very much on the conservative side.

58. Transport planning in Germany is based on cost benefit analysis which includes an evaluation of environmental effects. However, according to work commissioned by the Umweltbundesamt environmental effects are still inadequately considered, monetary values do not correspond with recent research results and projects are neither assessed as a network nor in comparison with other transport modes. ${ }^{71}$ Transport really needs to be considered as an integrated network with complementary modes rather than broken down into individual components for the purposes of determining which part accounts for what levels of emissions. In the absence of a network policy, discussion with respect to transport has often stressed the advantages of inter-modal substitution: switching from road transport to rail, from private to public transport, and from air to rail. Indeed, evidence does suggest widely differing energy use per unit of service. ${ }^{72}$ However, the scope for substitution is often limited for economic and technological reasons. Although the situation is gradually improving, the railways have been inefficiently run and have not been competitive with road transport in many areas. Moreover, despite a building programme for terminals to transfer cargo from road to rail the capacity of the lines is limited; 80 per cent of the volume is carried by only 50 per cent of the rail network so that extensive rail building would be required to raise substitution and this raises the issue of cost recovery, which for rail transport appears to be low.

59. Policy options are limited by institutional constraints in the case of air transport and road freight. Kerosene for air transport is not taxed at present, despite clear environmental externalities. Introduction of a tax requires unanimous consent of the EU. For road transport, most indicators point to the need to raise taxes on diesel which would affect both cars and road transport. However, fixed fees for German based transport companies are higher than in neighbouring countries so that the government has been under pressure to avoid placing domestic operators at a disadvantage. Proposals to levy a road tax on foreign trucks runs against EU law with respect to national treatment. The best method would be to move to a system of road user charges for all trucks, which is becoming technically feasible. Such a move would, however, require changes in the regulatory regime, in particular a lowering in the relatively high fixed costs levied on road transport.

60. Policy with respect to automobiles has varied from voluntary agreements to changes in tax treatment. German car producers have agreed to lower by 25 per cent (2005 in comparison with 1990) average fuel consumption on cars sold in Germany while the government has been furthering development of a fuel-efficient three litre per $100 \mathrm{Km}$ auto. While engine fuel consumption has improved, the weight of cars has also increased (thereby raising actual consumption) as consumers have preferred larger more comfortable and secure autos. Lower energy prices in comparison with the 1970s have led to a clear change in consumer preferences. To counter this tendency, the automobile tax was reformed in 1997 and is now based more on emissions than on car weight. Older cars, which are responsible for some 60 per cent of emissions, now pay some four times the basic rate. However, the tax differentiation is still only a fraction of that which could be expected on the basis of emissions alone and some observers judge that the

69. Efficient Transport for Europe: Policies for internalisation of External Costs, ECMT, OECD, Paris, 1998.

70. Kageson, (1993).

71. See Entwicklung eines Verfahrens zur Aufstellung umweltorientierter Fernverkehrskonzepte als Beitrag zur Bundesverkehrswegeplanung, Umweltbundesamt, Berlin, March 1998.

72. “Energieverbrauch im Verkehr in Deutschland”, DIW Wochenbericht, 10/99, March (1999b). 
tax structure favours diesel technology over petrol, which is at odds with other policy targets. ${ }^{73}$ There is still a need to shift taxes away from the type of car to actual use. The use of private transport is also conditioned by a number of fiscal measures related to other policy objectives. The tax treatment of company cars was changed several years ago for fiscal reasons but a side effect has been a move toward smaller cars for company fleets. Another important factor has also been the deductibility of private transport to and from work from income tax. The new government has sought to widen tax exemptions to include public transport so as to make the system more mode neutral.

61. In sum, road pricing will need to be tightened both with respect to passenger and road transport. In practice this will mean increases in both petrol and diesel taxes with more pronounced rises in the latter. On the other hand, some fixed taxes on both cars and trucks should at the same time be reduced. With respect to railways, a balance needs to be maintained between environmental objectives and economic considerations: efficiency needs to be raised as infrastructure cost recovery is the lowest of any transport mode.

\subsection{Agriculture}

62. . Production-linked support policies have led to a number of environmental problems including methane gas emissions, a high level of nitrates in ground water and increasing encroachment of natural habitats. ${ }^{74}$ These environmental problems have been due to high concentrations of livestock in some regions, intensive land use and resort to large quantities of fertiliser and pesticides. ${ }^{75}$ Although support policies are now less linked to output than they were in the past, and subsidies for the use of light fuels are being phased out, farmers are still facing distorted market and policy signals. Moreover, the polluter pays principle is hardly applied. Fertiliser use per hectare is limited by regulation rather than through a nitrogenbased fertiliser tax which would also affect fertiliser use up to the legal limit. Rather subsidies are often used, a case in point being the water charge which is used to compensate farmers for the limitation of fertiliser use. Organic farming has been growing rapidly and now accounts for 1.8 per cent of arable land use. Revenues from organic farming are some 15 to 35 per cent lower than those achieved by conventional methods so that its spread has been supported not only by consumer preference but also by new subsidy programmes of the EU and the federal and state governments.

63. In the agricultural sector policies to promote economic efficiency would also serve to support the achievement of environmental objectives. The current level of output-related support needs to be reduced but this will not obviate the need for selected taxes to be applied on inputs such as fertilisers. More importantly, the polluter pays principle also needs to be extended to this sector.

\section{Assessment: realising the aim of sustainable growth}

64. Overall, air and water emissions have been drastically reduced for many substances during the past twenty years, and the environmental quality of water resources, the soil and the air has improved in many instances. However, the reduction in emissions of many substances during the 1990s has been slower than in the 1980s and the gains which have been achieved are mainly due to developments in the new

73. H.J. Luhmann, "Die neue Kfz-Steuer ist halbherzig", Der Tagesspiegel, 25 June 1997. The need for a greater differentiation of tax rates is reported in the same article to be based on calculations by the Bundesumweltamt.

74. The OECD's Environmental Performance Review of Germany in 1993 emphasised that Germany uses nitrogen fertilisers relatively intensively, concluding that from a social point of view fertiliser used per unit of area is too high.

75. Agriculture and the environment: Issues and policies, OECD, Paris, 1998. 
Länder: western German emissions often have been stagnating or even increasing, whereas those in the new Länder have been falling at a pace comparable to the earlier developments in the west. While the reliance on direct regulation and voluntary agreements has achieved the desired emission cuts in the case of stationary emission source this has been less the case for mobile or non-point sources. The tendency for emission reductions to slow could indicate that the inexpensive or even zero-cost options in environmental policy are about to be exhausted -- at least in western Germany -- and that for a number of pollutants Germany is entering the area of increasing marginal costs of abatement.

65. If the above analysis is correct, the reliance of environmental policy on voluntary agreements, subsidies, regulation, information and on education may not now be enough to create the appropriate incentives for further emission reductions at least cost. Since additional reductions might only be achieved at rising marginal abatement costs there will be a greater need to take an economy-wide approach when considering environmental policy, and to integrate sectoral policy more closely in such a framework. In moving ahead, attention will have to be given to defining environmental targets more clearly and to rebalancing the regulatory framework with a greater use of economic instruments. The latter are more efficient at ensuring least cost abatement provided they are broad-based. In that case, environmental policies might result in a "double dividend", in the sense of meeting labour market and environmental goals simultaneously, but a more selected approach could lead to an inefficient choice and setting of policy instruments. The ecological tax reform of 1999 can be seen as an example of how labour-market and competitiveness issues can compromise the achievement of environmental policy targets. As a result, neither target is likely to be met effectively. In rebalancing the policy framework, a key condition will be to develop a regulatory framework which is compatible with the use of economic instruments, where these are appropriate. Proposals to unify environmental policies into a Code of Environmental Law (Umweltgesetzbuch) have been made by academics ${ }^{76}$ and by a commission of the Ministry of the Environment ${ }^{77}$ and need to be implemented.

66. Economic instruments may be difficult to use in some complex cases where monitoring costs are high or where the emissions are unusually complex, but in many cases they may offer advantages. For example, the environmental problems related to traffic and agriculture are difficult to control by regulatory instruments. Traffic-related emissions come from a large number of small and mobile sources which are difficult to regulate directly. Agricultural non-point pollution problems can not be directly controlled at the source. More generally, not all of the incentive structures support rational product design and development. Hence, a correction of prices through the use of economic instruments may be a superior choice. Economic instruments might also be highly effective in lowering $\mathrm{CO}_{2}$ emissions. To this end a priority will be to set energy tax rates more rationally so as to reflect relative emission intensities. Alternatively, tradeable permits might be considered which would fit more closely with proposed international quota mechanisms. In the case of global-warming issues, however, German domestic policy with respect to $\mathrm{CO}_{2}$ emissions cannot hope to achieve much in isolation although the demonstration effect is certainly important. Rather, policy also needs to be directed at encouraging the development of taxation and permit trading at an international or European level and at establishing project-based mechanisms. Germany is a good example of why such instruments could offer great advantages. Arguably, the investment in environmental protection in the new Länder has brought more returns in terms of improved environmental quality in Europe than if the same resources had been used in the old Länder.

67. A key determinant of the efficiency of potential policy measures -- either of a sectoral or overall focus -- is the efficiency of individual markets. OECD Economic Surveys of Germany have drawn attention to a number of inefficient markets, which will in turn lower the efficiency of policies directed towards the environment and might themselves serve to worsen the outcome. The agriculture sector is a good example of distorted markets leading to negative environmental affects in some regions, as are

76. Kloepfer et al. (1990).

77. BMU (1998). 
subsidies for coal production. Urban sprawl which, inter alia, impacts on land use, biodiversity and transport associated pollution is in part encouraged by the pattern of public support for homebuilding, and rent laws fail to give sufficient incentive to tenants and proprietors to save energy. ${ }^{78}$ At a minimum, some form of comparison between rents gross of heating costs could be considered which would minimise changes to the existing legal framework. ${ }^{79}$ The electricity market has been highly regulated up to recently and although it has held energy prices high, this has scarcely been for the right reasons and innovation and energy conservation have been discouraged. A factor which has been holding back a more rational approach to policy instruments has been the unresolved issue of nuclear energy, as a reliable timetable for its phasing out still needs to be agreed. In all the above cases, the relevant markets are either practically non-existent or are still highly distorted. Effectively addressing the microeconomic reform issues involved would lead to both increased economic efficiency and a more cost-effective achievement of environmental targets.

78. Hentrich, (1999). Some estimates point to potential energy savings of up to 90 per cent in old buildings. There is a special loan programme to encourage better insulation of accommodation if carried out as part of a renovation.

79. There are proposals to include information about heating costs when providing specifications of a house for sale. 


\section{Glossary}

Acidification

Acid rain

Anthropogenic

BAU

$\mathrm{Bcm}$

Biomass

Biotope

$\mathrm{CH}_{4}$

CHP

$\mathrm{CO}_{2}$

End-of-pipe

Eutrophication

FCCC

FGD

GHG

GW

GWh

ha

HFC

IEA

$\mathrm{kW}$

kWh

$\mathrm{Mcm}$
Caused by atmospheric emissions of sulphur dioxide and nitrogen oxides which, through "acid rain", lead to deposition of sulphur and nitrogen in the soil and water surfaces (causing damage to aquatic life and forests)

Describes a type of pollution which washes out of the atmosphere as dilute sulphuric and nitric acids

Describes an object or disturbance to the environment which is man-made or which follows from the emissions of harmful substances as a result of human activities

Business As Usual

Billion cubic metres

The total quantity of weight of organisms in a given area or volume

The smallest subdivision of a habitat, characterised by a high degree of uniformity in its environmental conditions and in its plant and animal life

Methane

Combined production of heat and power; sometimes, when referring to industrial CHP, the term "co-generation" is used.

Carbon dioxide

Technology which seems to remove pollutants from gases or liquids after the industrial process and before discharge into the environment

A process of pollution that occurs when a lake or stream becomes over-rich in algae or aquatic plants due to nutrient leaching (nitrogen and phosphorous) which kill animal life by depriving it of oxygen

Framework Convention on Climate Change

Flue-gas desulphurisation

Greenhouse Gas

Gigawatt, or 1 watt $\times 10^{9}$

Gigawatt-hour $=$ one gigawatt $\mathrm{x}$ one hour, or one watt $\mathrm{x}$ one hour $\mathrm{x} 10^{9}$

Hectare

Hydrofluorocarbons

International Energy Agency

Kilowatt, or 1 watt $\mathrm{x} 10^{3}$

Kilowatt-hour $=$ one kilowatt $\mathrm{x}$ one hour, or one watt $\mathrm{x}$ one hour $\mathrm{x} 10^{3}$

Million cubic metres 


\section{Glossary (continued)}

Mt

Mtoe

MvA

MWh

NMVOC

$\mathrm{N}_{2} \mathrm{O}$

$\mathrm{NO}_{x}$

Particulates

PFC

Sequestration

Sink

$\mathrm{SO}_{2}$

$\mathrm{SO}_{\mathrm{x}}$

TFC

Toe

Tonne

TPES/GDP

TPES

TW

TWh

VOC
Million tonnes

Million tonnes oil equivalent; see toe

Megawatt of electricity or 1 watt x $10^{6}$

Megawatt hour

Non-methane volatile organic compounds

Nitrous oxide

Nitrogen oxides

Tiny flecks of soot and similar substances in the atmosphere. A principal source of particulates is black exhaust from road vehicles

Perfluorocarbons

Term used in Kyoto Protocol. Absorption of $\mathrm{CO}_{2}$ by a sink, often a growing forest

In this context, a place where, or a process by which, greenhouse gases are removed from the atmosphere

Sulphur dioxide

Sulphur oxides

Total final consumption of energy; the difference between TPES and TFC consists of net energy losses in the production of electricity and synthetic gas, refinery use and other energy sector uses and losses

Tonne of oil equivalent, defined as $10^{7} \mathrm{kcal}$

Metric ton (10 $0^{3}$ kilograms)

A ratio of total primary energy supply (in Mtoe) to GDP (measured in billions of US dollars at 1990 prices and exchange rates); energy intensity

Total primary energy supply

Terawatt, or 1 watt $\times 10^{12}$

Terawatt $\mathrm{x}$ one hour, or one watt $\mathrm{x}$ one hour $\mathrm{x} 10^{12}$

Volatile Organic Compound 
ECO/WKP(2001)2

\section{ANNEX I. PROJECTIONS OF EMISSIONS TO 2005}

1. In view of the detailed regulatory instruments which are a feature of German environmental policy, projecting $\mathrm{CO}_{2}$ emissions presents a number of challenges and uncertainties. The IKARUS model (Stein and Strobel, 1997) attempts to establish a projection framework by specifying various technologies at a quite detailed sectoral level. This allows projections to be related to specific policy measures and sectors. As an optimisation model, it has also been used to calculate shadow prices for different levels of efficient emission control. Criticisms of such an approach include the macroeconomic assumptions and the way in which relative prices are allowed to impact on energy use and emission levels.

2. Estimates of carbon dioxide emissions derived from this model indicate that, taking account of all policy decisions made up to 1996, Germany is likely to fall short of its target emission level in 2005 by a large margin (Table A1). Subsequent policy initiatives, including the energy tax, which became effective in April 1999, have not been sufficient to alter this conclusion substantially. The environmental effect of the energy tax is considered by most observers to be small, one study reporting an optimistic scenario of at most a 2 per cent further reduction in carbon dioxide emissions (ZEW (1999)). Further announced increases for 2000 and 2001 would not seem to alter this conclusion significantly. The major contribution in terms of carbon dioxide reductions comes from activities not related to traffic. Total emissions of carbon dioxide in 2005 are expected to be 863.7 million tonnes, compared with 998.2 million tonnes in 1990. This is an expected reduction of 13.5 per cent compared with the target of 25 per cent set by the government. Private households, road traffic, and electricity demand are the sectors contributing in an accounting sense for the shortfall relative to target. With respect to other greenhouse gases, only for fluorocarbon (CFC) substitutes is an increase observable and this is expected to continue. The percentage reduction in carbon dioxide is below that expected for other important greenhouse gases, such as methane and nitrogen oxide (Table 3).

3. Nitrogen oxide emissions, having fallen in the 1980s and 1990s, are expected to increase again. The same is true for the volatile organic compounds. However, the projected near-term increase is even larger. Despite the significant reduction in emissions, progress has not been enough to arrest the damage and destruction of forests, although the large-scale forecast deterioration in German forests has been avoided (Box 1). 
Table A1. Projections of $\mathrm{CO}_{2}$ emissions

With policies in force as of 1996, in million tons of $\mathrm{CO}_{2}$

\begin{tabular}{|c|c|c|c|c|c|}
\hline & \multirow{2}{*}{1990} & \multirow{2}{*}{1995} & \multicolumn{2}{|c|}{ Scenario } & \multirow{2}{*}{$\begin{array}{c}\begin{array}{c}\text { Percentage } \\
\text { change }\end{array} \\
1990 / 2005\end{array}$} \\
\hline & & & 2000 & 2005 & \\
\hline Industry & 169.7 & 126.8 & 116.9 & 107.1 & -36.9 \\
\hline Small users & 75.7 & 51.9 & 61.6 & 56.5 & -25.4 \\
\hline Households & 128.4 & 135.2 & 115.9 & 110.7 & -13.8 \\
\hline Traffic & 184.9 & 196.1 & 223.0 & 224.0 & 21.1 \\
\hline Final energy users & 558.8 & 509.9 & 517.5 & 498.4 & -10.8 \\
\hline Electricity production & 353.6 & 317.5 & 316.7 & 318.9 & -9.8 \\
\hline District heating & 42.9 & 31.7 & 30.0 & 27.5 & -35.9 \\
\hline Other energy production & 43.0 & 24.0 & 21.0 & 19.0 & -55.8 \\
\hline Energy sector & 439.4 & 373.2 & 367.8 & 365.3 & -16.9 \\
\hline Total emissions & 998.2 & 883.1 & 885.3 & 863.7 & -13.5 \\
\hline
\end{tabular}

Source: Stein and Strobel (1997).

Table A2. Development of pollutant emissions

In kilotonnes

\begin{tabular}{|c|c|c|c|c|c|c|c|}
\hline & \multirow{3}{*}{1970} & \multirow{3}{*}{1980} & \multirow{3}{*}{1990} & \multirow{3}{*}{1996} & \multirow{3}{*}{$\begin{array}{c}2005 \\
\text { (expected) }\end{array}$} & \multicolumn{2}{|c|}{ Change } \\
\hline & & & & & & $\begin{array}{l}\text { Change } \\
1990 / 96\end{array}$ & $\begin{array}{c}\text { Change } \\
1996 / 2005\end{array}$ \\
\hline & & & & & & \multicolumn{2}{|c|}{ Per cent } \\
\hline Sulphur dioxide $\left(\mathrm{SO}_{2}\right)$ & 7720 & 7510 & 5326 & 1850 & 990 & -65 & -46 \\
\hline Nitrogen oxides ( $\mathrm{NOx}$ ) & 2690 & 3330 & 2640 & 1868 & 2130 & -31 & +14 \\
\hline NMx-VOCs & 2477 & 3220 & 3155 & 1920 & 2700 & -41 & +40 \\
\hline Dust & 3270 & 2609 & 2024 & 518 & n.a. & -74 & .. \\
\hline
\end{tabular}

Source: BMU (1998a), IWG (1998). 


\section{BIBLIOGRAPHY}

Adams, J. (1997), "Environmental Policy and Competitiveness in a Globalised Economy: Conceptual Issues and a Review of the Empirical Evidence", paper prepared for the Workshop on Economic Globalisation and the Environment, Vienna.

Barker, T. (1999), "Limits of the Tax Approach for Mitigating Global Warming", in J. Hacker and A. Pelchen (eds.), Goals and Economic Instruments for the Achievement of Global Warming Mitigation in Europe, Kluwer Academic Publishers.

Beermann, Wilhelm (1998), "Neuordnung des Deutschen Steinkohlenbergbaus", Glückauf, Vol. 134, No. 9.

Bill, S. (1999), "European Commission's Experience in Designing Environmental Taxation for Energy Products", in J. Hacker and A. Pelchen (eds.), Goals and Economic Instruments for the Achievement of Global Warming Mitigation in Europe, Kluwer Academic Publishers.

Böhringer, Christoph et al. (1997a), "Volkswirtschaftliche Effekte einer Umstrukturierung des deutschen Steuersystems unter besonderer Berücksichtigung von Umweltsteuern". Forschungsbericht 37, University of Stuttgart.

Böhringer, Christoph et al. (1997b), "Ökosteuerstudien im Vergleich -- eine wissenschaftliche Zwischenbilanz", Discussion Paper, Institut für Energiewirtschaft und Rationelle Energieanwendung (IER), Stuttgart.

Borchers, Jens (1996), Privatisierung staatlicher Forstbetriebe", Eine ökonomische Analyse zur Deregulierung im Bereich der Forstwirtschaft, Schriften zur Forstökonomie, Frankfurt.

British Petroleum Company (BP) (1997), Statistical Review of World Energy, London.

Bundesministerium für Landwirtschaft (BML) (1996a): “Agrarbericht der Bundesregierung", Bundesdrucksache, Bonn.

BML(1996b), Waldzustandsbericht der Bundesregierung 1996, Bonn.

BML (1997), Waldzustandsbericht der Bundesregierung 1997, Bonn.

Bundesumweltministerium (BMU) (1996), Water Resources Management in Germany, Bonn.

BMU (1997), Towards Sustainable Development in Germany, Bonn.

BMU (1998a), Sustainable development in Germany: Draft programme for priority areas in environmental policy, Bonn.

BMU (1998b), Umweltgesetzbuch (UGB-Kommission-Entwurf), Berlin.

BMU (1998c), 1998 Report on the Environment, Bonn.

BMU (1998d), Federal Government Report under the Convention on Biological Diversity, Bonn. 


\section{ECO/WKP(2001)2}

Bundesministerium für Wirtschaft und Technologie (BMWi) (1998), Energiedaten 97-98.

Bundesregierung (IWG) (1998), Fourth Report of the carbon dioxide Reduction Interministerial Working Group, Bonn 1998.

Buttermann, Hans Georg and Bernhard Hillebrand (1996), Regionalwirtschaftliche Auswirkungen von Steuern und Abgaben auf den Verbrauch von Energie -- Das Beispiel Nordrhein-Westfalen, Essen.

Buttermann, Hans Georg and Bernhard Hillebrand (1998), Carbon dioxide-Monitoring in German Industry: Target Achievement in 1997, RWI, Essen.

Deutscher Bundestag (1997), "Konzept Nachhaltigkeit -- Fundamente für die Gesellschaft von morgen", Zwischenbericht der Enquete Kommission: Schutz des Menschen und der Umwelt -- Ziele und Rahmenbedingungen einer nachhaltig zukunftsverträglichen Entwicklung, 13. Deutscher Bundestag, Bonn.

Deutscher Bundestag (1998a), Abschlußbericht der Enquete-Kommission, Schutz des Menschen und der Umwelt -- Ziele und Rahmenbedingungen einer nachhaltig zukunftsverträglichen Entwicklung, Drucksache 13/11200, 26 June 1998, Bonn.

Deutscher Bundestag (1998b), Konzept Nachhaltigkeit -- Vom Leitbild zur Umsetzung, Abschlußbericht der Enquete-Kommission", Schutz des Menschen und der Umwelt, Drucksache 13/11200, 26 June 1998, Bonn.

Deutsches Institut für Wirtschaftsforschung (DIW) (1994), Wirtschaftliche Auswirkungen einer ökologischen Steuerreform, Research report for Greenpeace, Berlin.

DIW et al., (1996), Updated Calculation of Jobs Induced by Environmental Protection in Germany.

Döring, Thomas, (1998), “Europäische Umweltpolitik nach Amsterdam”, Wirtschaftsdienst, 1998/III.

Conrad, Klaus and Tobias Schmidt, (1997),"Double dividend of climate protection and the role of international policy co-ordination in the EU -- An applied general equilibrium analysis with the GEM-E3 model", ZEW Discussion Paper, 97-26.

Elsasser, Peter (1996), "Der Erholungswert des Waldes“. Monetäre Bewertung der Erholungsleistung ausgewählter Wälder in Deutschland" Schriften zur Forstökonomie, Frankfurt.

Enquete Kommission (1995), "Mehr Zukunft für die Erde", Schlußbericht der Enquete Kommission, "Schutz der Erdatmosphäre", des 12., Deutschen Bundestages, Bonn.

EU (1992), Environmental Action Programme.

Faber, Malte et al. (1998), Umdenken in der Abfallwirtschaft, Heidelberg.

Hansmeyer, Karl-Heinz (1989), "Fallstudie: Finanzpolitik in Dienste des Gewässerschutzes", in Klaus Schmidt (Hrsg.), Öffentliche Finanzen und Umweltpolitik, Band 2, Berlin, pp. 47-76.

Hampicke, U., K. Tampe, H. Kiemstedt, T. Horlitz, M. Walters, and D. Timp (1991), "Kosten und Wertschätzung des Arten- und Biotopschutzes", Berichte des Umweltbundesamtes, 3/91, Berlin.

Heinloth, Klaus (1997), Die Energiefrage, Bedarf und Potentiale, Nutzung, Risiken und Kosten, Braunschweig. 
Heister, Johannes, et al. (1990), "Umweltpolitik mit handelbaren Emissionsrechten -- Möglichkeiten zur Verringerung der Kohlendioxid- und Stickstoffemmissionen", Kieler Studien No. 237, J.C.B. Mohr, Tübingen.

Hentrich, Steffen, (1999), "Energieeinsparung im ostdeutschen Mietwohnungsbestand: Mehr Investitionsanreize notwendig", Wirtschaft im Wandel, 5. Hübler, O. (1997), "Evaluation beschäftigungspolitischer Massnahmen in Ostdeutschland", Jahrbücher für Nationalökonomie und Statistik, Vol. 216/1.

Hom-Müller, K., H. Hansen, M. Klockmann, and P. Luther (1991), "Die Nachfrage nach Umweltqualität in der Bundesrepublik Deutschland" Berichte des Umweltbundesamtes, 4/91, Berlin.

Huckestein, Burkhard (1996), "Effizienzbedingungen ökonomischer Instrumente in der EU-Umweltpolitik. Voraussetzungen für den Einsatz von Umweltabgaben und -lizenzen auf Gemeinschaftsebene", Beiträge zur Umweltgestaltung, Band A 135, Berlin.

Institut für Empirische Wirtschaftsforschung (IEW) (1997), "Was kostet eine Reduktion der Karbondioxyd-Emissionen?", Report No. 55, University of Osnabrück.

International Energy Agency, (1997), Germany 1998 Review, OECD.

Jänicke, Martin and Helmut Weidner (1997), "Germany”, in Martin Jänicke et al., National Environmental Policies: A Comparative Study of Capacity-Building, Berlin.

Klepper, Gernot et al. (1995a), "Industrial Metabolism”, Kieler Studie No. 268, Tübingen.

Klepper, Gernot and Peter Michaelis (1995b), Packaging Waste in the European Union, LS Research. Banbury.

Klepper, Gernot and Christian Scholz (1998), "Wirkung und Ausgestaltung einer ökologischen Steuerreform", Zeitschrift für Wirtschaftspolitik, Vol. 47, No. 1.

Kloepfer, M. et al. (eds.) (1990), Umweltgesetzbuch -- Allgemeiner Teil, Berlin.

Köhler, S. (1994), "Bewertung des Waldes im Rahmen der gesamtwirtschaftlichen Vermögensrechnung", Spektrum, Bd. 2, Bundesstatistik, Wiesbaden.

Lechner, M. (1999), An evaluation of public-sector sponsored continuous vocational training programmes in East Germany, University of St. Gallen.

Linckh, Günther, H. Sprich, H. Flaig, and H. Mohr (1997), Nachhaltige Land- und Forstwirtschaft. Vorraussetzungen, Möglichkeiten, Maßnahmen, Berlin.

Maas, Claus (1987), "Einfluß des Abwasserabgabengesetzes auf Emissionen und Innovationen”, Zeitschrift für Umweltpolitik und Umweltrecht, Vol. 10, pp. 65-85.

Meyer, Renschhausen, Martin (1990), "Ökonomische Effizienz und politische Akzeptanz der Abwasserabgabe", Zeitschrift für Umweltpolitik und Umweltrecht, Vol. 13, pp. 43-66.

Michaelis, Peter (1995), "Product Stewardship, Waste Minimization and Economic Efficiency: Lessons from Germany", Journal of Environmental Planning and Management, Vol. 38, No. 2, pp. 231-243.

Michaelis, Peter (1996), Ökonomische Instrumente in der Umweltpolitik, Heidelberg. 
Müller, E., (1986), Innenwelt der Umweltpolitik --(Ohn) Macht durch Organisation?, Westdeutscher Verlag.

Neu, Axel D. (1995), "Subventionen ohne Ende? Steinkohlenbergbau und Energieverbrauch in Deutschland", Kieler Diskussionsbeiträge, No. 248.

OECD, (1993), Environmental Performance Reviews: Germany, Paris.

OECD, (1998), Agriculture and the Environment, Paris.

OECD, (1999a), "Policy challenges arising from climate change", OECD Economic Outlook, 65, Paris, June 1999.

OECD, (1999b), Voluntary Approaches For Environmental Policy In OECD countries: An Assessment, Paris, 1999.

OECD, (1999c), The Price of Water, Paris.

OECD, (1999d), Implementing Domestic Tradeable Permits for Environmental Protection, Paris.

Rennings, K, K. Brockmann and H. Bergmann, (1997), "Voluntary agreements in Environmental Protection: Experience in Germany and future perspectives", Business Strategy and the Environment, Vol. 6, No 5.

RWI, (1999a), Stellungnahme zum Entwurf eines Gesetzes zum Einstieg in die ökologische Steuerreform, Deutscher Bundestag, January 1999.

RWI, (1999b), Stellungnahme zum Entwurf eines Gesetzes zur Fortführung der ökologischen Steuerreform, Essen, October 1999.

Sachverständigenrat zur Begutachtung der gesamtwirtschaftlichen Entwicklung (SVR) (1998), "Vor weitreichenden Entscheidungen", Jahresgutachten 1998/1999, Stuttgart.

Scholz, Christian (1999), "Environmental Tax Reforms and the Double Dividends -- A Theoretical and Empirical Analysis for Germany", mimeo, Kiel Institute of World Economics.

Sachverständigenrat für Umweltfragen SRU (1994), Umweltgutachten 1994, Wiesbaden.

SRU (1995), Umweltgutachten 1995, Wiesbaden.

SRU (1996), Umweltgutachten 1996, Wiesbaden.

SRU (1997), Umweltgutachten 1997, Wiesbaden.

SRU (1998), Umweltgutachten 1998, Wiesbaden.

SPD (1998), Koalitionsvereinbarung zwischen der Sozialdemokratischen Partei Deutschlands und Bündnis 90/Die Grünen, Bonn.

Stein, Gotthard and Bernd Strobel (eds.) (1997), Politikszenarien für den Klimaschutz -- Untersuchungen im Auftrag des Umweltbundesamtes, Vol. I and Vol. II, Jülich. 
Storchmann, Karl-Heinz and Petros Kyro (1997), Steinkohlenbergbau im Ruhrgebiet -- Entwicklung, Subventionen, Beschäftigungseffekte, Ruhr-Forschungsinstitut für Innovations- und Strukturpolitik, Bochum.

Umweltbundesamt, (UBA) (1994),“Umweltqualitätsziele, Umweltqualitätskriterien, und -standards: Eine Bestandaufnahme”, UBA-Texte 64/94, Berlin.

UBA, (1997a), "Grundlagen für ein nationales Umweltindikatorensystem", Forschungsbericht 10105016, UBA-FB 97-022, Berlin.

UBA, (1997b), Nachhaltiges Deutschland -- Wege zu einer dauerhaft umweltgerechten Entwicklung, Berlin.

Verheyen, Roda and Joachim H. Spangenberg (1998), Die Praxis der Kreislaufwirtschaft, Friedrich-EbertStiftung, Bonn.

Welfens, Paul and R. Hillebrand, (1998), "Environmental Problems in the Single EU Market: Developments, Theory and New Policy Options", European Institute for International Economic Relations, Potsdam, mimeo.

Wuppertal, (1995), Zukunftsfähiges Deutschland, Wuppertal Institut für Klima, Umwelt und Energie.

ZEW, (1999), "Was bringt die ö kologische Steuerreform der deutschen Wirtschaft", ZEW Konjunkturreport, February, 1999. 


\section{ECONOMICS DEPARTMENT}

\section{WORKING PAPERS}

275. Central Control of Regional Budgets : Theory with Applications to Russia (January 2001) John M. Litwack

274. A Post-Mortem on Economic Outlook Projections (December 2000) Vassiliki Koutsogeorgopoulou

273. Fixed Cost, Imperfect Competition and Bias in Technology Measurement: Japan and the United States (December 2000) Kiyohiko G. Nishimura and Masato Shirai

272. Entry, Exit, and Aggregate Productivity Growth: Micro Evidence on Korean Manufacturing (December 2000) Chin-Hee Hahn

271. The Tax System in Korea: More Fairness and Less Complexity Required (December 2000) Thomas Dalsgaard

270. A Multi-Gas Assessment of the Kyoto Protocol (October 2000) Jean-Marc Burniaux

269. The Changing Health System in France (October 2000) Yukata Imai, Stéphane Jacobzone and Patrick Lenain

268. Inward Investment and Technical Progress in the UK Manufacturing Sector (October 2000) Florence Hubert and Nigel Pain

267. Aggregate Growth: What have we Learned from Microeconomic Evidence? (October 2000) John Haltiwanger

266. Determinants of Long-term Growth: A Bayesian Averaging of Classical Estimates (BACE) Approach (October 2000) Gernot Doppelhofer, Ronald I. Miller and Xavier Sala-i-Martin

265. The Great Reversals: The Politics of Financial Development in the $20^{\text {th }}$ Century (October 2000) Raghuram G. Rajan and Luigi Zingales

264. Trade and Growth: Still Disagreement about the Relationship (October 2000) Robert Baldwin

263. Growth Effects of Education and Social Capital in the OECD Countries (October) Jonathan Temple

262. Human Capital in Growth Regressions: How Much Difference Does Data Quality Make? (October 2000) Angel de la Fuente and Rafael Doménech

261. Raising the Speed Limit: US Economic Growth in the Information Age (October 2000) Dale W. Jorgenson and Kevin J. Stiroh

260. Summary of an Informal Workshop on the Causes of Economic Growth (October 2000) Jonathan Temple

259. Knowledge, Technology and Economic Growth: Recent Evidence from OECD Countries (October 2000) Andrea Bassanini, Stefano Scarpetta and Ignazio Visco 
258. Average Effective Tax Rates on Capital, Labour and Consumption (October 2000) David Carey and Harry Tchilinguirian

257. The Health Care System in Poland (September 2000) Nathalie Girouard and Yutaka Imai

256. Public Expenditure Reform: The Health Care Sector in the United Kingdom (August 2000) Vincent Koen

255. Regulatory Reform in Road Freight and Retail Distribution (August 2000) Olivier Boylaud

254. Regulation, Market Structure and Performance in Air Passenger Transportation (August 2000) Rauf Gonenc and Giuseppe Nicoletti

253. Policy Interdependence during Economic Transition: the Case of Slovakia 1999-2000 (June 2000) Joaquim Oliveira Martins and Tristan Price

252. E-Commerce: Impacts and Policy Challenges (June 2000) Jonathan Coppel

251. The Implementation and the Effects of Regulatory Reform: Past Experience and Current Issues (June 2000) Rauf Gonenc, Maria Maher and Giuseppe Nicoletti

250. The Concept, Policy Use and Measurement of Structural Unemployment: Estimating a Time Varying NAIRU across 21 OECD Countries

(June 2000) Pete Richardson, Laurence Boone, Claude Giorno, Mara Meacci, David Rae and David Turner

249. Options for Reforming the Spanish Tax System

(June 2000) Isabelle Joumard and Aristomène Varoudakis

248. Economic Growth in the OECD Area: Recent Trends at the Aggregate and Sectoral Level (June 2000) Stefano Scarpetta, Andrea Bassanini, Dirk Pilat and Paul Schreyer

247. Economic Effects on the 1999 Turkish Earthquakes: an Interim Report (June 2000) Alexandra Bibbee, Rauf Gonenc, Scott Jacobs, Josef Konvitz and Robert Price

246. Policy Influences on Economic Growth in OECD Countries: an Evaluation of the Evidence (June 2000) Sanghoon Ahn and Philip Hemmings

245. The Tax System in the Czech Republic (May 2000) Chiara Bronchi and Andrew Burns

244. The Tax System in Norway: Past Reforms and Future Challenges (May 2000) Paul van den Noord

243. A Changing Financial Environment and the Implications for Monetary Policy (May 2000) Paul Mylonas, Sebastian Schich, Gert Wehinger

242. Carbon Emission Leakages: a General Equilibrium View (May 2000) Jean-Marc Burniaux and Joaquim Oliveira Martins 